\title{
Recent Laborian of the Peyrazet cave-rock shelter (Creysse, Lot, France). New data for the end of Lateglacial in Quercy
}

Le Laborien récent de la grotte-abri de Peyrazet (Creysse, Lot, France). Nouvelles données pour la fin du Tardiglaciaire en Quercy

Véronique Laroulandie, Jérémie Jacquier, Sandrine Costamagno, Pierre Chalard, Jean-Baptiste Mallye, Jean-Marc Pétillon, Solange Rigaud, Aurélien Royer, Luca Sitzia, David Cochard, Laure Dayet, Célia Fat Cheung, Olivier Le Gall, Alain Queffelec and François Lacrampe-Cuyaubère

\section{OpenEdition} Journals

\section{Electronic version}

URL: http://journals.openedition.org/paleo/3027

DOI: 10.4000/paleo.3027

ISSN: $2101-0420$

\section{Publisher}

SAMRA

\section{Printed version}

Date of publication: 1 December 2015

Number of pages: 79-116

ISSN: 1145-3370

\section{Electronic reference}

Véronique Laroulandie, Jérémie Jacquier, Sandrine Costamagno, Pierre Chalard, Jean-Baptiste Mallye, Jean-Marc Pétillon, Solange Rigaud, Aurélien Royer, Luca Sitzia, David Cochard, Laure Dayet, Célia Fat Cheung, Olivier Le Gall, Alain Queffelec and François Lacrampe-Cuyaubère, "Recent Laborian of the Peyrazet cave-rock shelter (Creysse, Lot, France). New data for the end of Lateglacial in Quercy ». PALEO [Online], 26 | 2015, Online since 26 April 2016, connection on 07 July 2020. URL : http:// journals.openedition.org/paleo/3027 ; DOI : https://doi.org/10.4000/paleo.3027

This text was automatically generated on 7 July 2020.

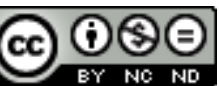

PALEO est mis à disposition selon les termes de la licence Creative Commons Attribution - Pas d'Utilisation Commerciale - Pas de Modification 4.0 International. 


\title{
Recent Laborian of the Peyrazet cave-rock shelter (Creysse, Lot, France). New data for the end of Lateglacial in Quercy
}

\author{
Le Laborien récent de la grotte-abri de Peyrazet (Creysse, Lot, France). Nouvelles \\ données pour la fin du Tardiglaciaire en Quercy
}

Véronique Laroulandie, Jérémie Jacquier, Sandrine Costamagno, Pierre Chalard, Jean-Baptiste Mallye, Jean-Marc Pétillon, Solange Rigaud, Aurélien Royer, Luca Sitzia, David Cochard, Laure Dayet, Célia Fat Cheung, Olivier Le Gall, Alain Queffelec and François Lacrampe-Cuyaubère

The authors thank the DRAC Midi-Pyrénées, in particular the Service Régional de l'Archéologie, and the Lot Conseil Général for financial support for this project. We also thank P.-L. Lasfargues and P. Jardel for authorizing access to the site of Peyrazet and work there since 2008. Thanks to G. Delfour who began the geoarchaeological study, to N. Cantin (IRAMAT-CRPP2A, Bordeaux university Montaigne) for the x-ray diffraction analyses on the ochre object, to L. Bruxelles for the contextual geomorphological data, to G. Saint-Sever for examining the pottery shards found on the surface in the shelter and in the first clearings, to C. Oberlin and D. Roux for the Artémis dates, to F. Echassériaud (association Archéologies), G. Bariviera (sté TSM), S. Ducasse for some of the lithic drawings (Archéologies-CG 46 contract), to B. Gravina for the translation of the abstract and the captions. We also thank the two reviewers of this article, B. Valentin and $L$. Detrain, for their constructive comments, as well as C. Boussat for her editorial work. Finally, we extend warm thanks to the volunteers who participate in this archaeological experience each year.

\section{Introduction}

Prehistoric Upper Quercy lies between the Aquitaine Basin and the Massif Central and is a well-known domain from a historiographical perspective for Tardiglacial 
occupations (Lorblanchet 1972). Nonetheless, apart from the recent excavations carried out in the Lot at the Murat Rock shelter (Rocamadour; Lorblanchet 1989, 1996), Sanglier (Reihac; Séronie-Vivien dir. 2001) or at Pégourié (Caniac- du-Causse; Séronie-Vivien dir. 1995), and currently at Cuzoul de Gramat (Valdeyron et al. 2011), the end of the Palaeolithic from this region is mainly documented by collections issued from early works (end $19^{\text {th }}$ - early $20^{\text {th }}$ centuries), particularly those of $\mathrm{F}$. Bergougnoux, A. Viré and Abbot Lemozi (fig. 1a). The Laborian was not identified as such at the time - the authors preferred to refer to the Azilian or the Late Magdalenian - and only two sites yielded remains from this period in the region: Malaurie Rock shelter at Rocamadour (Niederlander, Lacam, Sonneville-Bordes 1956), the eponymous site of a backed point with a truncated base which became one of the main markers of the Laborian (Coulonges 1963; Le Tensorer 1979; Célérier 1998), and Roc d'Abeilles at Calviac (Champagne \& Espitalié 1970). The recent revision of these two series compared to other sites in Aquitaine enabled us to propose the attribution of some of the material to the Laborian (Langlais et al. 2014a).

2 In this context, the discovery of a complex attributed to the Laborian from the caveshelter of Peyrazet (Creysse, Lot), a site surveyed by P. Chalard in 1991 and excavated each year since 2008 (ibid.), presented the opportunity to provide new data relating to regional settlement during the Pleistocene/Holocene transition. The site of Peyrazet is located between the Causses de Martel in the north and Gramat in the south, $300 \mathrm{~m}$ from the right bank of the Dordogne (fig. 1a). The cavity is situated at an NGF altitude of $127 \mathrm{~m}$, opens towards the SE about twenty metres above the valley floor (fig. 1c). It is an ancient karstic gallery carved into the limestone massifs of the Dogger (Upper Bajocian and Lower Bathonian) which was cut into when the Dordogne Valley was incised. The gallery is about $1.50 \mathrm{~m}$ wide in the upper sector. It opens out rapidly towards the slopes, resulting in a rock shelter morphology, with a present-day width of about $10 \mathrm{~m}$ at the entrance (fig. 1b). The Laborian complex overlies a significant Upper Magdalenian deposit, but is separated from it by an interface with Azilian elements (Langlais \& Laroulandie \& coll. 2009). The upper Laborian complex (layers 1 and 2) was excavated over a surface of $12 \mathrm{~m} 2$ (fig. 2a). The thickness of the Laborian levels varies from one sector to another (fig. 2b), and they were not identified over the whole excavated surface. They are mainly concentrated in the upper part of the site (fig. 2a). 
Figure 1 - a: Peyrazet and other regional Late Glacial sites (map base by M. Jarry, INRAP, Illustration $\mathrm{ML})$, b: plan of the cave-rock shelter indicating the excavated area, c: sagittal transect (b-c: CAD Archéosphere).

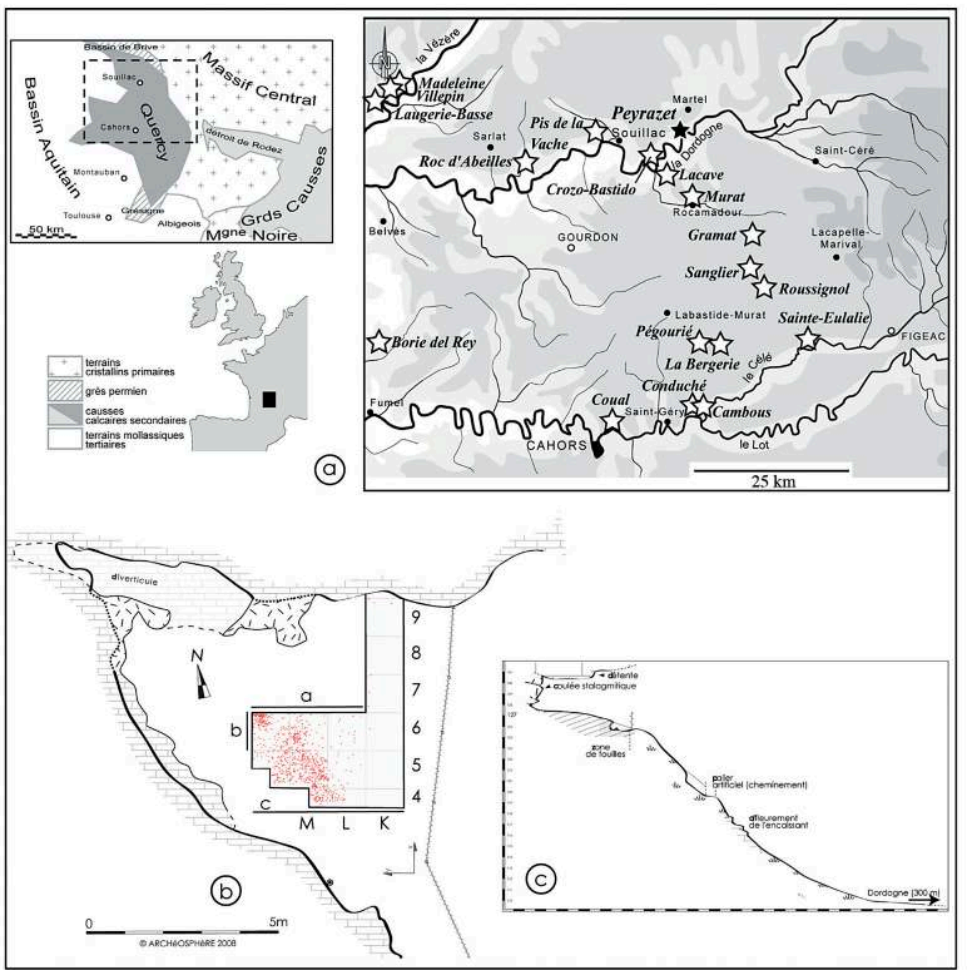


Figure 2 - a: projection (plan view) of the remains from levels $1 \& 2$; b: vertical projection of plotted finds and sieved fraction from all levels (excavation seasons 2008-2014, in red: levels 1 \& 2).
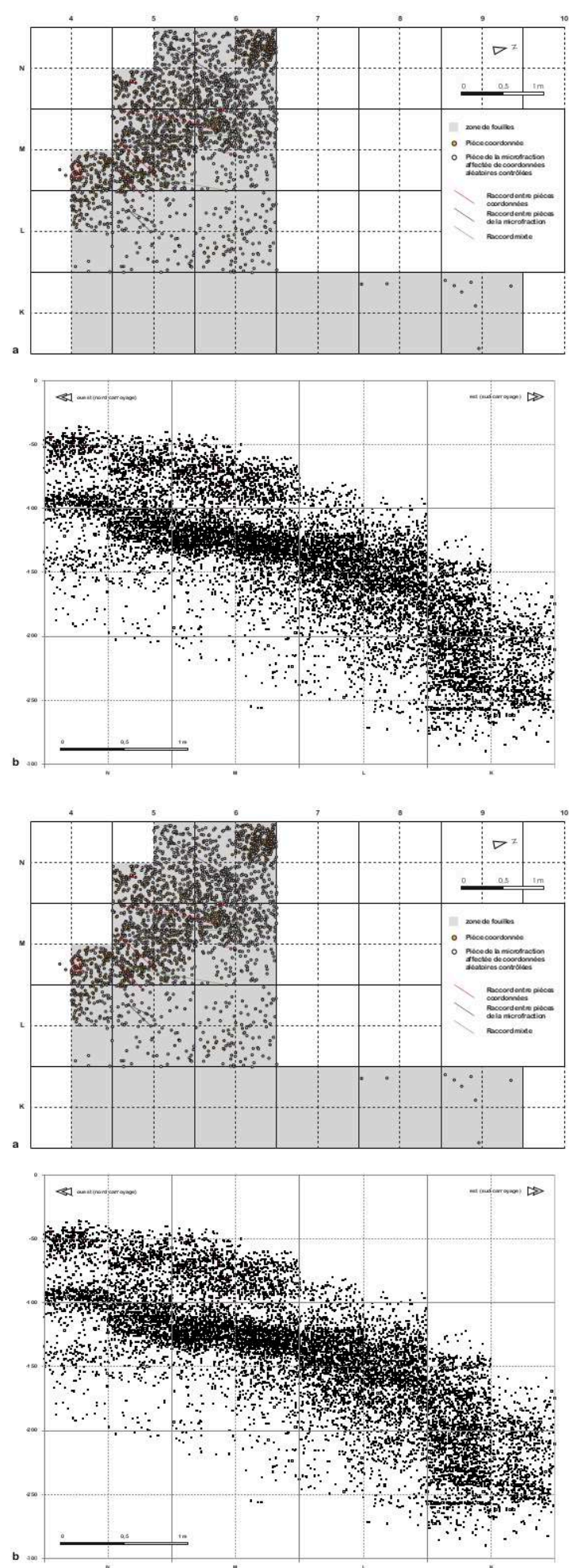


\section{Geoarchaeology}

3 At the present time, the thickness of the sedimentary infilling can be estimated at at least $150 \mathrm{~cm}$. The excavation exposed a NS oriented frontal profile as well as two sagittal profiles (north and south, fig. 1). The main sequence is visible in the north sagittal profile and consists of three main units, from the top to the base.

\section{North sagittal profile (fig. 3a)}

Unit 1 is about $60 \mathrm{~cm}$ thick and is slightly inclined towards the east. At the top, a biomacrostructured calcareous horizon A, with a thickness of about $10 \mathrm{~cm}$ corresponds to a Holocene rendzina. The root system penetrates down to the base of the unit where the lower limit is diffuse. The main lithofacies is a massive diamicton matrix support. Moving towards the porch, the unit rapidly contains more coarse fraction and the diamicton is more clastic. The matrix corresponds to a brownish-yellow silty clay (10YR 6/8) with limestone gravel ( 1 to $2 \mathrm{~cm}$ ). The coarse fraction is dominated by angular limestone stones of less than $10 \mathrm{~cm}$ on average and by rare blocks of 10 to $40 \mathrm{~cm}$. The diamictic facies is typically observed in slope deposits and can result from the action of several sedimentary processes, such as debris flow or run-off (Bertran 2004). As bioturbation affects the whole unit, typical sedimentary run-off structures (sorting figures, stratification) are not visible and it is thus difficult to identify run-off as the main sedimentary agent. In fossil environments, this is a common problem (Lenoble 2005). Furthermore, although the diamictic facies is observed for solifluction and debris flows, the overall stratigraphic organization of the unit is not in accordance with the descriptions given in active environments for the deposits associated with these sedimentary agents (Bertran 2004). Thus the most likely hypothesis is that run-off from the endokarst and the shattering of the rock shelter walls are the main processes causing the accumulation of this unit. The Laborian complex (layers 1 and 2), which is the focus of this article, is in this geological unit.

Unit 2 appears on the whole profile and presents a dip of about $8^{\circ}$ towards the east. In the west sector, it is $30 \mathrm{~cm}$ thick and increases rapidly towards the slope. As the excavation is still ongoing, the base of the unit is not totally visible in the east: it reaches a thickness of at least $100 \mathrm{~cm}$. The lithofacies corresponds to a massive diamicton with matricial to clastic organization. The stones and plates are angular and generally less than $10 \mathrm{~cm}$ in size. The matrix is silty-sandy and dark yellowish-brown in colour (10YR 4/6). Three sub-units were identified. Sub-unit $2 b$ is differentiated by enrichment in organic matter and a very dark brown colour (10YR2/2). It gradually changes to unit $2 \mathrm{c}$ identified by a matricial support with a more abundant and less carbonated silty fine fraction. In the east sector, nearly all of the sediments are strongly impregnated with secondary carbonates. Unit 2 , which by and large presents the same facies as unit 1, results from the combined action of run-off and shattering. Sub-unit $2 b$ indicates the formation of a humiferous horizon. Unit 2 corresponds to the archaeological layers c.3: the Azilian interface and c.4: the Upper Magdalenian.

6 Unit 3 is made up of a deposit of blocks and slabs with sizes varying between 10 and 50 $\mathrm{cm}$ and with blocks reaching sizes of one or several metres in the lower part. The base of this unit has not yet been reached. Towards the top, the matricial structure is made up of brownish-yellow carbonated sandy-clayey silts (10YR 6/8), with no macroscopic 
traces of biological activity. The structure becomes semi-open to open in the sectors with abundant large blocks. The dip of these blocks varies between $22^{\circ}$ and $29^{\circ}$ towards the east, in keeping with the overall dip of the unit towards the valley. All the information suggests that unit 3 corresponds to a scree level accumulated during a rebalancing phase of the vault. This unit corresponds to layer 5 of the archaeostratigraphy.

\section{Frontal and sagittal south profiles (fig. $3 \mathrm{~b}$ and c)}

We briefly present these two complementary profiles due to the significant differences they present in relation to the north sagittal profile.

The frontal profile is situated at the western end of band 6 (fig. 1b) and is oriented N-S. It represents the link between the north and south sagittal profiles. The succession of units 1,2 and 3 described above (fig. $3 b$ ) is visible in the northern half. It is not observed in the southern part of the profile and this change is marked by a clear erosion limit, of irregular appearance, running vertically through units 1 and 2 (fig. 3b). The observed stratigraphic succession at the south of the erosion limit is organized into two complexes. The first is a surface horizon $(0-30 \mathrm{~cm})$, made up of grey-brown siltyclayey sands (2.5Y 5/2), with a structure of clearly identifiable sub-rounded aggregates. Many angular to sub-angular limestone stones are dispersed throughout the horizon. Roots are abundant and micro-charcoals are present. Under this horizon $(30-150 \mathrm{~cm})$, we observe a sequence of infra-decimetric yellow bedding and pale yellowish-brown beds with a thickness varying between 10 and $30 \mathrm{~cm}$. Limestone stones and plaquettes are dispersed or poorly aligned. We also note the presence of stony stratification about $10 \mathrm{~cm}$ thick with clastic substrate. The beds present a slight dip towards the south and are made up of a mixture of aggregates of different colours, ranging from brownishyellow to dark brown. They are of spherical to sub-spherical shape with an average size of less than $1 \mathrm{~cm}$. In the lower right corner of the unit, an altered zone is clearly visible. It is characterized by an enrichment in carbonates, which cover the stones as crusts, and by the very loose nature of the sediment. 
Figure 3 - Levé des coupes A : sagittale nord, B : frontale est, C : sagittale sud. Figure 3 - Profiles A: north sagittal, B: east frontal, C: south sagittal.
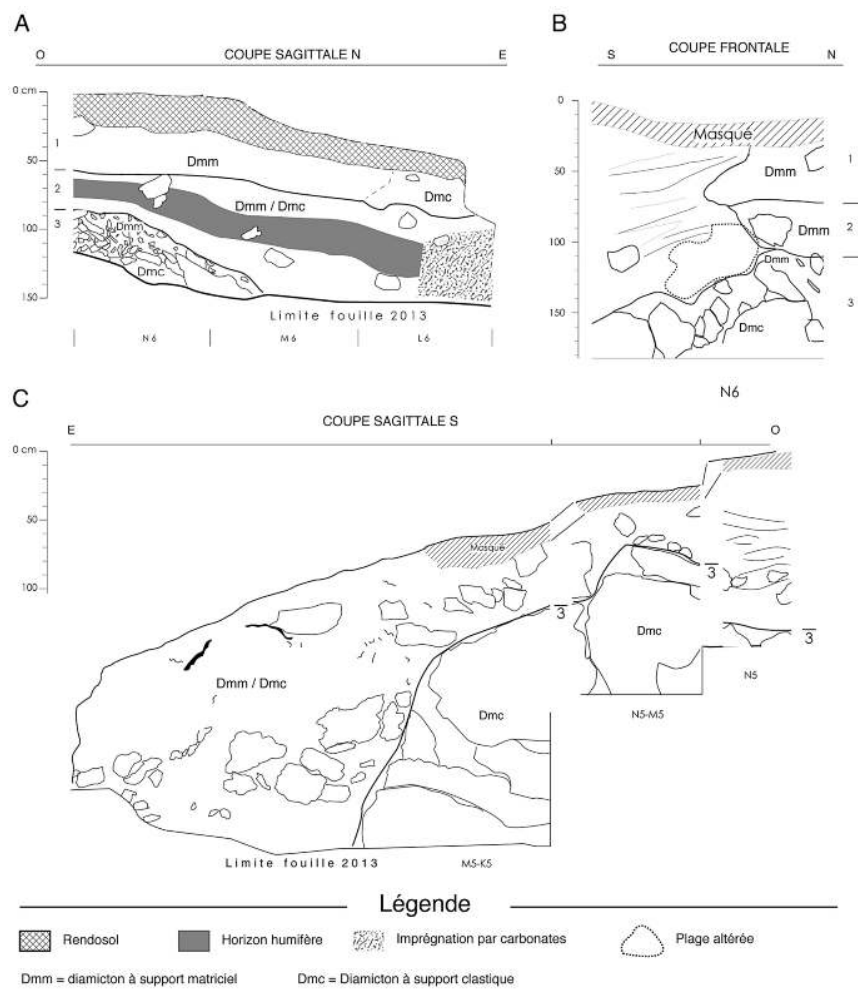

9 The west part of the south sagittal profile (fig. 3c) is characterized by the absence of units 1 and 2. Like in the southern half of profile $G$, these units are replaced by alternating pale yellowish-brown and yellow sandy-silty beds, a mixture of aggregates of different colours, and the presence of stony lenses. The lower part of the profile corresponds to unit 3 and displays continuity along the whole excavated complex in the southern half of the site. In the eastern part, we observe the sequence of units 1,2 and 3 described in the north sagittal profile, although the transition between the different units is less clear due to strong carbonate impregnation and intense root bioturbation.

The stratigraphy of the south sagittal and frontal profiles shows the presence of erosional stratigraphic discontinuity in the south-western sector of the site. This is situated in the sector furthest to the west (fig. 3c), and only affects the upper half of the sequence. The observed lithofacies in frontal profile, and in particular the presence of beds with a mixture of aggregates of different colours which appear to correspond to units 1 and 2, suggest that these two units were reworked in the southwest part of the site. In addition, the absence of Holocene rendzina at the top of the sequence points to a relatively recent age for this reworking. The reworked lithofacies is interpreted as the result of important bioturbation linked to burrow digging by large burrowers (fox or badger). The main criteria are the deconstruction of the original stratigraphic units and the rounded aggregate structure of the deposits with a mixture of sediment from both units. These criteria are partly in agreement with the observations made during the study of the biofacies characterizing present-day badger burrows (Mallye 2007). In the beds with slight dips, we could not observe the classification of the typical particles of excavation cones at burrow entrances (ibid.). We thus consider that the observed facies indicates the fill of one or several internal galleries of the burrow(s). This fill could have occurred in association with badger activities (development and cleaning of 
the burrows) and the progressive collapse of the galleries. The stony lenses could be linked to the development of the entrance of secondary galleries. This interpretation requires confirmation in so far as there is currently no detailed description of the lithofacies characteristic of the internal areas of badger burrows. Nonetheless, the burrow hypothesis appears to be coherent, and is consistent with the mesofauna which shows the presence of young carnivores (including the badger, see below). Reworked facies comparable to those observed at Peyrazet are also observed in fills of archaeological pits or in the backfill of early excavations. Nonetheless, at least three arguments are in disagreement with such an interpretation: absence of remains from historic times in the excavated zone; no evidence of an early excavation; significant spatial coherence of the archaeological layers between the different sectors of the site (refits between bands 5 and 6, fig. 2a).

\section{Faunal spectrum}

11 The macrofaunal spectrum for the Laborian complex is dominated by the red deer (Cervus elaphus, $73.6 \%$ of the ungulate NRD: tab. 1). It is completed by several roe deer remains (Capreolus capreolus), boar (Sus scrofa), Bovines, horse (Equus caballus), chamois (Rupicapra rupicapra) and ibex (Capra ibex). The presence of the reindeer (Rangifer tarandus, NR=5) in this context is questionable. Indeed, this ungulate was dominant in the underlying levels of the Upper Magdalenian and the aforementioned bioturbation and the stratigraphic discontinuity of the Azilian layer may explain its presence in this layer. In addition, direct dates on the remains of this species in the southwest of France indicate that it disappeared around $14 \mathrm{ky}$ (millennia) cal. BP (Costamagno et al. 2009; Szmidt et al. 2009; Drucker, Madelaine, Morala 2011; Langlais et al. 2012). It was not possible to date these remains due to their poor preservation, but we consider the reindeer to be intrusive in the upper complex of Peyrazet.

Mesomammals are represented by four carnivore and two Leporidae genera (tab. 1). Due to the fragmented state of the fox remains, the species could not be determined. The remains consist of milk teeth with marked root resorption. The only determined badger remain is a first upper molar with non-formed roots attributed to a severalmonth-old animal. The six remains of the Martes genus are immature and could belong to the same animal. The bone epiphyses are missing and the teeth are decidual. On account of the low number of polecat remains and the absence of diagnostic elements, the European polecat (Mustela (Putorius) putorius), cannot be distinguished from the steppe polecat (Mustela (Putorius) eversmanni) or the European mink (Mustela lutreola). Three weasel/ermine remains, seven wild rabbit remains (Oryctolagus cuniculus) and five hare remains (Lepus sp.) were also identified.

The avifauna from the upper complex belongs to several disparately represented taxonomic orders (tab. 1). Passeriformes are abundant and form nearly two-thirds of the corpus. Five of these remains are related to the Corvidae family, and in particular, to the western jackdaw (Corvus monedula), as well as to a larger species, the carrion crow or the rook (Corvus corone/frugilegus). The other Passeriforme bones have not been determined, but belong to several species similar in size - or smaller than - the blackbird. At least three Galliforme species are recorded: the grey partridge (P. perdix), the quail (C. coturnix) and the domestic hen (G. Gallus domesticus), which appears to be 
intrusive (see below). In this order, a proximal carpo-metacarpal fragment could belong to a ptarmigan (cf. Lagopus).

Table 1 - Faunal spectrum of the upper Peyrazet sequence (excluding rodents). Taxon with * are intrusive.

\begin{tabular}{|c|c|c|c|}
\hline TAXONS & $N R$ & TAXONS & $N R$ \\
\hline Bovinès & 3 & Anatidés & 6 \\
\hline Rupicapra rupicapra/Chamois & 9 & Rapace diurne & 4 \\
\hline Capra ibex/Bouquetin & 2 & Falcosp. & 1 \\
\hline Caprinès-Ovicaprinés & 1 & Galliformes & 3 \\
\hline Cervus elaphus/Cerf élaphe & 95 & cf. Lagopus & 1 \\
\hline Rangijer tarandus/Renne & $5^{*}$ & Perdix perdix, Perdrix grise & 4 \\
\hline Capreolus capreolus/Chevreuil & 5 & cf. Perdix perdix & 1 \\
\hline Cervidés & 4 & Coturnix coturnix, Caille des blés & 2 \\
\hline Sus scrofa/Sanglier & 3 & cf. Coturnix coturnix & 1 \\
\hline Equus caballus/Cheval & 2 & Gallus domesticus* & 2 \\
\hline Total NRDt Ongulés & 129 & Strigiformes & 1 \\
\hline Mammifêres de grande taille & 9 & Charadiriformes & 1 \\
\hline Mammifêres de moyenne ou grande taille & 14 & Passériformes & 118 \\
\hline Mammiferes de moyenne taille & 357 & Corvidés & 2 \\
\hline Mammiferes de petite ou moyenne taille & 51 & Corvus monedula & 1 \\
\hline Mammifêres de petite taille & 30 & Corvus corone/frugilegus & 2 \\
\hline Mammiferes de petite ou très petite taille & 4 & Aves & 41 \\
\hline Mammiferes de très petite taille & 11 & Total aves & 191 \\
\hline Mammifêres & 14718 & Cyprinidés (cf. Chevaine/Vandoise) & 29 \\
\hline Total Ongulés & 15323 & Anguillidés (cf. Anguille) & 20 \\
\hline Vulpes sp.Renard s.I. & 3 & Salmoninés (of. Truite/Saumon) & 15 \\
\hline Meles meles/Blaireau & 1 & Esocidés (cf. Brochet) & 2 \\
\hline Martes sp./Martre ou Fouine & 6 & inder & 28 \\
\hline Mustela (Putorius) sp./Putois s.l. & 4 & Total ichyofaune & 94 \\
\hline Mustela nivalis/erminea/Belette ou Hermine & 3 & & \\
\hline Petî̀ carnivore indét. & 2 & & \\
\hline Lepus sp./Lièvres.l. & 5 & & \\
\hline Oryctolagus cumiculus/Lapin & 7 & & \\
\hline Lèporidé indèt. & 1 & & \\
\hline Total Mésofaune & 32 & & \\
\hline
\end{tabular}


Table 2 - List of small mammals from the upper Peyrazet sequence and modern data from owl pellets collected around Martel (data from LPO Lot), * $=$ intrusive.

\begin{tabular}{|c|c|c|c|}
\hline TAXONS & Actuel & Couche 1 & Couche 2 \\
\hline Apodemus sylvaticus/Mulot sylvestre & $\mathrm{x}$ & $\mathrm{x}$ & $\mathrm{x}$ \\
\hline Apodemus flavicollis/Mulat à collier & & & $\mathrm{x}$ \\
\hline Anvicola terrestris/Canpagnol terrestre & & $\mathrm{x}$ & $\mathrm{x}$ \\
\hline Cricetus cricetus/Hamster européen & & $\mathrm{x}$ & $\mathrm{x}$ \\
\hline Glis glis/Loir gris & & $\mathrm{x}$ & \\
\hline Microtus agrestis/Campagnol agreste & $\mathrm{x}$ & $\mathrm{x}$ & $\mathrm{x}$ \\
\hline Microtus arvalis/Campagnol des champs & $\mathrm{x}$ & $\mathrm{x}$ & $\mathrm{x}$ \\
\hline Microtus aeconomus/Campagnol nordique & & $\mathrm{x}$ & $\mathrm{x}$ \\
\hline Micratus (Terricola) pyrenaicus/Campagnol des Pyrénées & $\mathrm{x}$ & & \\
\hline Myodes glareolus/Campagnol roussätre & $\mathrm{x}$ & $\mathrm{x}$ & $\mathrm{x}$ \\
\hline Mus musculus/Souris domestique & $\mathrm{x}$ & & \\
\hline Rattus rattus/Rat noir * & $\mathrm{x}$ & $\mathrm{x}$ & \\
\hline Crocidura russula/Musaraigne musette & $\mathrm{x}$ & & $\mathrm{x}$ \\
\hline Crocidura indet./Cracidure indet. & & $\mathrm{x}$ & $\mathrm{x}$ \\
\hline Savex coronatus-araneus/Musaraigne couronnée-carrelet & $\mathrm{x}$ & $\mathrm{x}$ & $\mathrm{x}$ \\
\hline Sorex minutus/Musaraigne pygmée & $\mathrm{x}$ & & $\mathrm{x}$ \\
\hline Talpa europaea/Taupe d'Europe & & $\mathrm{x}$ & $\mathrm{x}$ \\
\hline Myotis nattereri/Vespertilion de Natterer & & $\mathrm{x}$ & \\
\hline
\end{tabular}

14 Several nocturnal and diurnal birds of prey are present, including a small indeterminate falcon. Anatidae are represented by several fragments and one Charadriiforme was identified.

Layers 1 and 2 contained 94 fish remains, including 66 determined remains (tab. 1). The estimated size of the Salmonidae is $25-30 \mathrm{~cm}$ and the Cyprinidae $10-30 \mathrm{~cm}$, (one specimen of $45-50 \mathrm{~cm}$ ).

The observed capture seasons $(\mathrm{N}=22)$ for the Salmonidae, the pike and the Cyprinidae point to death during the fair season. Several batrachian remains were also found during sieving.

The upper complex yielded a small quantity of micromammal remains, in comparison to the lower layers. The analysed sample is not exhaustive and comes from about 1250 litres of sediment. The material was retrieved during wet sieving on a $1.6 \mathrm{~mm}$ mesh. Overall, a minimum of 77 individuals was identified, belonging to ten species of rodents and five insectivores. Layer 2 differs from layer 1 by the absence of the edible dormouse (G. glis) and the black rat (R. rattus, intrusive), and the presence of the yellow-necked mouse (Apodemus flavicollis) and shrews (Crocidura russula and Sorex minutus). In addition, three fragments of European hamster molars (C. cricetus) were identified at the base of c. 1 and the top of c. 2. These two fossil faunal spectra present many differences with the present-day faunal spectrum, obtained from pellets collected at Martel (about $7 \mathrm{~km}$ from the site; tab. 2). 


\section{Vertebrate taphonomy}

Out of the 385 large faunal remains observed from a taphonomic viewpoint, a single element may present carnivore marks. The bone remains comprise many postdepositional alterations and on $50 \%$ of the bones, over half of the cortical surface is not observable. Traces of roots, of corrosion/dissolution, desquamation and concretions are mainly responsible for this alteration. Fissures and breakdown could be linked to alternating humid and dry phases. The small sample size and the poor conservation of the surfaces limit the archaeozoological study.

The low number of bones from mesomammals, the poor preservation of some of them and the scarcity of predation marks did not enable us to identify all of the accumulation modes of the different taxa. Nonetheless, the presence of bone and dental remains from small carnivores (fox, badger, pine marten/beech marten, weasel/stoat), particularly from young animals, implies that the site was used as a place of refuge for these different taxa for part of the year (end of spring - beginning of summer). This result could also be correlated with the identification of a burrow at the excavation (see above). Besides the small carnivores and wild rabbits, of as of yet unknown origin, two hare remains present anthropogenic marks (see below).

avifauna includes the presence of two chicken bones at the top of the infilling which are clearly imputable to the pollution of this complex. One of the two fragments bears traces of ingestion indicating that it was brought by a carnivore, probably of small size. The clearing carried out during the first excavation season yielded several remains with recent patina also bearing this type of mark. These two pieces, alongside other indications, indicate a recent contamination of the sediment containing the Laborian material (see below). It is currently impossible to rule out the hypothesis of a wider contamination, concerning other taxa. Several remains present traces of slight digestion similar to those produced by nocturnal birds of prey. These are visible on Passeriforme, partridge, quail and diurnal raptor bones. A humerus from a small passerine also shows traces of digestion. In spite of the attentive observation of the bone surfaces, there is no evidence of the exploitation of birds by hunter-gatherers.

taphonomic study of the fish bones is still ongoing and it is thus difficult to determine the anthropogenic role in the accumulation of all or part of these ichthyological remains. The presence of small carnivores, birds and rodents accumulated by non-human predators nonetheless tends to indicate that some of the fish were not fished by the Laborian occupants.

Before proceeding with the climatic and environmental reconstructions based on rodents, it is necessary to examine the integral nature of the microfaunal complexes. Our results bring to light two species in c. 1 - R. rattus (NR=1) and M. oeconomus (NR=2) - which have never cohabited in the southwest of France (Le Louarn \& Quéré 2003). The first traces of R. rattus in France date to the first centuries B.C., whereas the last occurrences of M. oeconomus in the southwest of France were reported in the layers of Abeurador (Hérault), dated to the beginning of the Holocene towards 7-8 ky BP non cal (Marquet 1993). The R. rattus remain, as well as those of G. glis, were found in the very first clearances of the upper complex, which also yielded several protohistoric pottery remains. Conversely, the $\mathrm{M}$. oeconomus remains were identified at the base of c. 1 whereas c. 2 contained seven additional teeth from this taxon. There is no difference between the patinas of the bones and thus the disturbances cannot be distinguished. 
Moreover, there do not seem to be any spatial correlations, according to the grid and clearing, between the disturbed lithic or faunal remains and the M. oeconomus remains. Consequently, in view of these results and of the quantities of determined remains, and although it is difficult to confirm the "actual" presence of the tundra vole in c. 1, its presence in c. 2 would confirm the survival of this taxon at the beginning of the Holocene in the southwest of France.

\section{Environmental implications}

Besides the seemingly intrusive presence of the reindeer among the ungulates (see above), no glacial species is recorded in the upper complex. The roe deer and the boar indicate temperate climatic conditions. The discreet presence of Bovines and the horse and the predominance of the red deer point to rather open spaces. The chamois and the ibex attest to a rocky environment.

Like for the mesomammals, the avifaunal list provides little environmental information, as the rate of specific determination is low and the distribution areas of the determined species are broad. Apart from the element related to the ptarmigan, no other taxa are typical of glacial climatic conditions. This single remain could come from the Magdalenian complex where this species is well represented alongside the reindeer. The presence of Anatidae and jackdaws is compatible with the immediate surroundings of the site, which comprise humid and rocky environments for these species. The grey partridge and the quail indicate a landscape with open spaces.

For the micromammals, the environment around the site was reconstructed using the Jeannet method (2010), based on the taxonomic spectrum. Layers 1 and 2 present plant cover with a marked wooded component. Layer 1 tends towards a "high forest" type landscape whereas layer 2 presents higher percentages of "scrub" and "coppice" type vegetation. Both levels present important soil humidity. Layer 2 differs from layer 1 by a slightly more humid environment with "cool" and marshy soils and less "running water". Based on the BioClim method (Hernández Fernández 2001, 2006; Hernández Fernández \& Peláez-Campomanes 2003), the small mammal spectra from layers 1 and 2 outline a typically temperate climate (climatic zone VI) with two maximal probabilities (P1=1.000). This Bioclim, method, combined with the QnBMs climatic model (Hernández Fernández \& Peláez-Campomanes 2005), enables us to quantify the average annual temperature. The average annual temperature is estimated at $11.1 \pm 3.6^{\circ} \mathrm{C}$ for layer 1 , whereas layer 2 presents a lower annual average temperature estimated at $7.6 \pm$ $3.6^{\circ} \mathrm{C}$. This contrast may be pondered by recent bioturbations, especially in layer 1 . As for the European hamster, identified in layer 2 and the base of layer 1, it currently lives in the steppe and cereal fields of Central and Eastern Europe and was identified in the southwest of France during this period, thereby suggesting a cool event (recent Dryas or cold Preboreal oscillation?).

\section{Overview of the Laborian animal resources}

\section{The large fauna}

Some of the identified dental remains come from adult animals (red deer, roe deer, horse, ibex, chamois), while others come from immature individuals (red deer, 
chamois, boar). The presence of young animals is also attested by diaphyseal long bone fragments presenting a fibrous aspect. The discovery of two non-identified fetus remains is also noteworthy. All the elements of the red deer have been identified, apart from vertebrae, carpals/tarsals and the third phalanges. Ribs seem to be clearly underrepresented in relation to limb bones. This observation is confirmed if we also consider the anatomically determined remains. Considering these remains, vertebral fragments are always absent. Teeth are also rare. Out of the eleven identified dental remains, an almost complete row of incisors from the same individual - made up of seven teeth was discovered in connection. The other teeth correspond to small fragments. Apart from a worked fragment (see below), antler elements are absent.

In spite of the poor conservation of the bone surfaces, several pieces bear butchery marks. They correspond either to striations $(\mathrm{NR}=28)$ or impact marks $(\mathrm{NR}=16)$. These marks were mainly observed on red deer, caprinae and large bovinae long bone shaft fragments. A fragment of a red deer metatarsal bears a longitudinal mark on the posterior surface which could indicate the removal of the flexor tendons from a rear foot. In parallel, burnt bones are abundant; they represent more than half of the bone remains (use as fuel?). Whole bones are very rare: only two red deer sesamoids, a chamois first phalange, a roe deer second phalange and the fetus humerus are complete. According to the study of the fracture edges of the long bone shafts, as well as green bone fractures, secondary dry bone fragmentation affects more than $30 \%$ of the edges.

The low number of bone remains could indicate relatively short occupations and the absence of antlers (apart from the worked fragment) could point towards doe hunting at the end of the winter and/or in spring, at a time when red deer do not have antlers. Another possible hypothesis is that these portions were abandoned at the kill sites, which could be related to the decline in the use of cervid antler during this period. Although the post-cranial axial skeleton is clearly under-represented, undoubtedly due to the poor conservation of these bones, it is difficult to draw conclusions about the introduction of red deer carcasses (whole or quartered?). Whatever the case, the carcasses were exploited for their meat and marrow which were consumed on-site.

\section{Hare(s)}

Anthropogenically-produced marks were identified on two hare remains. A fragment of a tibia shaft bears cut marks and scraping marks. A distal end of a left humerus is marked on the lateral epicondyle by cutmarks, which appear to show the dismembering of the forelimb of the animal (Cochard 2004; Lloveras, Moreno- Garcia, Nadal 2009). This bone also presents traces of burning, indicating possible cooking near a source of heat (Vigne et al. 1981; Vigne \& Marinval-Vigne 1983). Nonetheless, other similar discoveries are required to confirm this hypothesis. Note that three hare remains were also identified in c. 7 of La Borie del Rey (Langlais et al. 2014b).

\section{Osseous industry}

The osseous industry from the upper layers of Peyrazet only comprises several objects. One object is a set of at least 
3149 fragments, most of which are less than a centimetre long. Sixteen of them were assembled to form five elements, the largest of which measures $45 \times 19 \times 4 \mathrm{~mm}$. The initial object appears to have been a rib section (from a medium or large-sized mammal) with completely scraped medial and lateral surfaces. The scraping striations are still clearly visible on each of the fragments. The object was then exposed to fire action, resulting in a change in colour and the destruction of the worked surface in several places, as well a weakening of the bone tissue which undoubtedly accelerated the fragmentation process. This piece is too fragmentary to attribute it to a specific typo-technological category; it could be a prepared bone block (cleaned) for future exploitation. The use of cervid antler is represented by a worked piece with a subquadrangular section ( $26 \times 10 \times 5 \mathrm{~mm}$ ) with post-depositional fractures on both ends and on one edge. The other edge bears a surface with regular and parallel striations pointing to debitage by longitudinal grooving. The taxonomic attribution (reindeer or red deer) remains indeterminate, as does the typo-technological attribution of this object: it could be a fragment of a finished object on a rod, a fragment of an unfinished rod, or even a fragment of grooving debitage waste. Unless we consider this object to represent contamination from the underlying Magdalenian level, this would appear to be the second archaeological example of debitage by longitudinal grooving from the Laborian. The only other mention to our knowledge is layer 2 of Pont-d'Ambon (rod extraction by double grooving on cervid antler: Célérier 1996, p. 90-91 and fig. 20).

Lastly, let us note the discovery of a flat harpoon barb and a bone awl obtained by scraping (similar to pieces from layers 7 and 3 of the eponymous site: Langlais et al. 2014b). These two objects cannot be confidently attributed to the upper complex on account of the presence of Azilian elements in the underlying complex.

\section{The lithic equipment}

Flint is the main raw material used by the Laborian hunter-gatherers of Peyrazet. Nonetheless, other rocks were also brought to the site as flat pebbles from the Dordogne. Among them, quartz/quartzites $(\mathrm{N}=13)$ are the only materials presenting the debitage of several small flakes on an anvil. However, due to the limited size of the corpus, we cannot be more specific. The others are fragmented metamorphic pebbles $(\mathrm{N}=65)$ and several basalts $(\mathrm{N}=4)$, which appear to have been used whole as macro-tools or as hearth loads. Two small zones of dismantled concentrations of more or less rubefied pebbles associated with micro-charcoals were also brought to light. The considerable arenization of metamorphic rocks, in particular micaschists, often obliterates any information. Four elements in quartz crystal complete the complex.

\section{Siliceous raw materials}

Apart from the tiny shards of less than a centimetre long ( $\mathrm{N}=2$ 887), the flint objects represent an assemblage of 1490 pieces divided into different blanks and materials (tab. 3). The systematic observation of these objects with a stereomicroscope resulted in the identification of several origins. The local flints (about $12 \%$ ) include the jasperoid and Bajocian materials (fig. 4, $\mathrm{n}^{\circ}$ 3-6), 3 pieces in Bathonian as well as several Tertiary flints. The jasperoid pebbles are available in the nearby Dordogne River deposits below the shelter and in the early terraces but also in the Hettangian silicifications on the right 
bank. The Bajocian flint outcrops in nearby deposits (alterites of the Gramat or Martel Causse, in particular Puy d'Issolud).

Table 3 - Representation of the different raw materials (SEN: Senonian, gn: grey-black, bd: blond, TER: Tertiary, JSP. “Jaspers”, BAJ: Bajocian, GDM: “grain-de-mil”, BV: Belvès, BAT: Bathonian) by blank type (SC: semi-cortical, EL: laminar flake, ELL: bladelet by-products, PL: small blade).

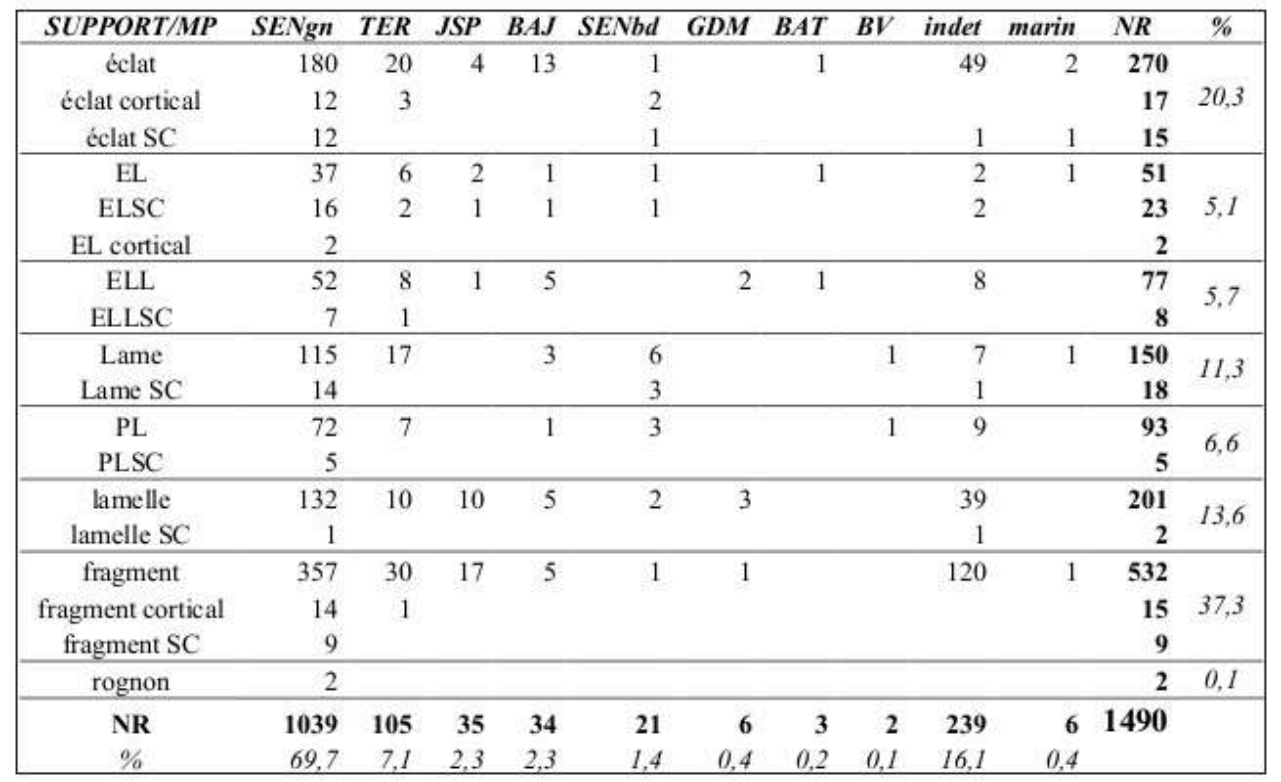


Figure 4 - Micropaleontological characters of specific lithic raw materials (1: "grain-de-mil", 2: Belvès subalveolina and orbitoides tissoti; 3-4: oolithic structure of Hettangian "jaspers", 5-6: Bajocian, 7-8: Tertiary gastropods and Chara). Raw materials exploited in the upper Peyrazet sequence (JSP. “jaspers”, Baj: Bajocian flints, Bat: Bathonian flints, TER: Tertiary flints, SEN: Senonian flints).

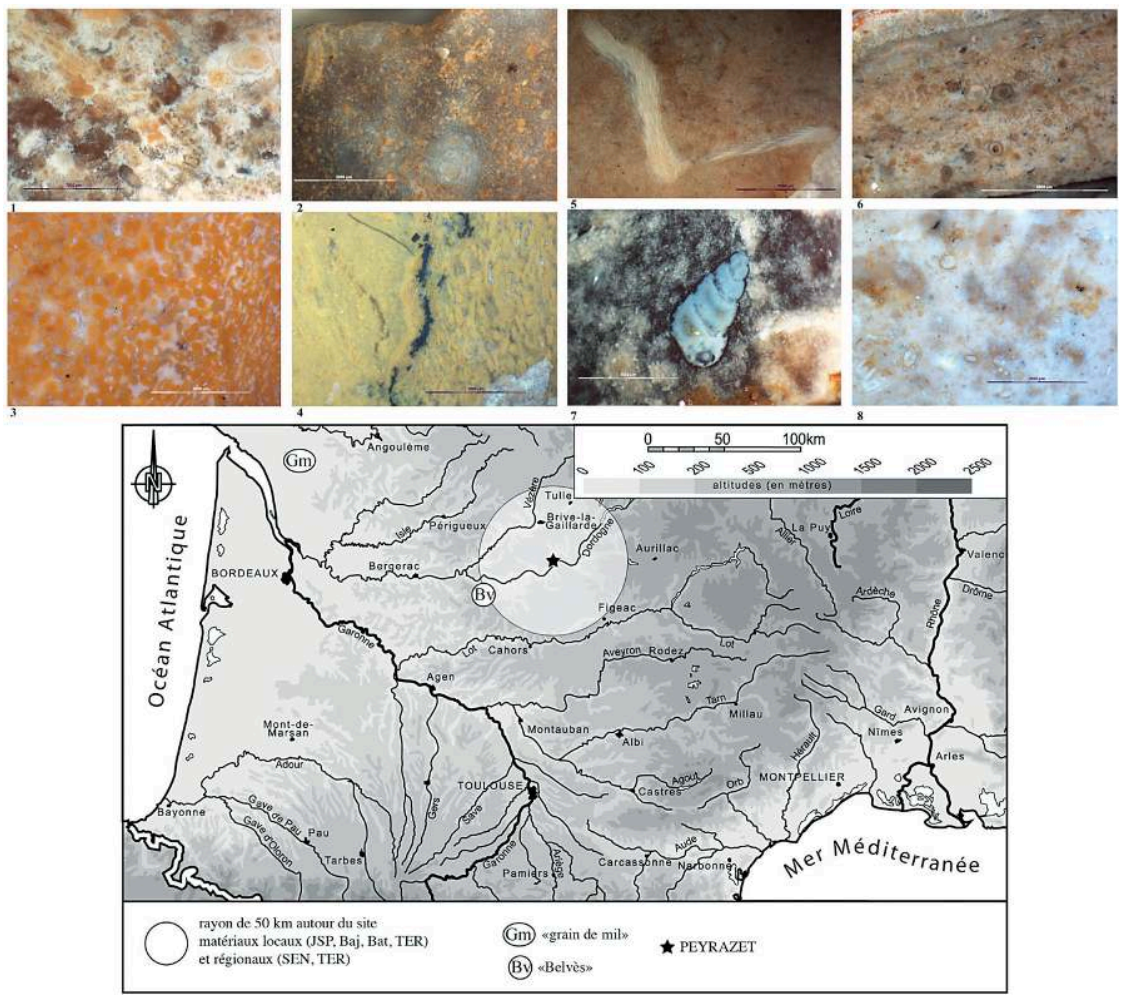

Bathonian flints - with sources on the surrounding limestone plateaus - are only represented by one piece. Lastly, pebbles in Tertiary flint, also available in the alluvial terraces near the site, complete the local raw materials (fig. 4, $\mathrm{n}^{\circ} 7-8$ ).

The allochthonous raw materials (approximately $72 \%$ ), are largely dominated by Senonian Perigord flint. The "grey-black" and "blond" components are available several tens of kilometres to the west of the site without necessarily crossing the Dordogne (Turq \& Morala and coll. 2014). The presence of several pieces in "grain-demil" flint (Simonnet \& coll. 2007; Caux 2014; fig. 4, $\mathrm{n}^{\circ} 1$ ) indicates a more distant origin, $250 \mathrm{~km}$ to the west, in Charente. The only material for which the Dordogne necessarily had to be crossed is a flint with large alveolina and orbitoides tissoti (fig. $4, \mathrm{n}^{\circ} 2$ ) from the region of Belvès to the southwest of the site (Turq 2000; fig. 4).

From a techno-economic viewpoint (tab. 3), the grey-black Senonian, the Tertiary and Bajocian flints were clearly knapped on site for lamino-lamellar production. Most of the blanks for tools and weaponries are in grey-black Senonian flint. On the other hand, the jasperoids are only used for the lamellar component, probably due to the relatively small dimensions of the initial volumes. The Belvès flint is recorded by a blade and a backed point. Finally, the "grain-de-mil" flint is represented by burin spalls and a fragment, indicating that tools were brought to the site. 


\section{Toolkit and domestic activities}

An almost exhaustive functional analysis of the lithic series was carried out ${ }^{1}$, according to the methodological principles defined by S. A. Semenov (1964) and applied by most specialists (e.g. Plisson 1985; Van Gijn 1989; Gassin 1996). In spite of mechanical alterations, the lithic assemblage is in a satisfactory state of conservation for studying usewear. Isolated or small groups of scalar chipping were probably generated by a combination of several post-depositional factors but only represent a minor loss of information. The fragmentation of the remains was a bigger problem. Indeed, nearly half of the identified used zones (ZU) are cut off by a break of indeterminate origin. This fragmentation sometimes made it difficult to reconstruct tool function. On the other hand, the state of conservation of the surfaces and the use polish is very good. Soil gloss, represented here by a fluid polish with relatively strong gloss, is visible on most of the pieces but does not alter the microtopography and only interferes with the interpretation of the most tenuous microtraces.

The relatively widespread white patina veil affected the quality of the microphotographic photos.

This "typo-techno-functional" approach showed that 57 pieces were considered as tools (tab. 4; fig. 5, fig. 6). The two main groups are knives and end scrapers. In addition, 36 burin spalls, some of which bear traces (prior to the coup de burin), five burins, several pièces esquillées and truncated blades (knives with worked ends). Most of the toolkit is made on rectilinear blades from the full debitage phase (see below). The functional analysis brought to light six main types of activities: carcass processing $(10 \mathrm{ZU})$, skin processing $(24 \mathrm{ZU})$, osseous materials $(2 \mathrm{ZU})$ and plants $(5 \mathrm{ZU})$, scraping of mineral materials $(3 \mathrm{ZU})$, direct or indirect percussion on hard organic matter $(6 \mathrm{ZU})$.

41 The knives are made up of non-retouched laminar blanks (fig. 7), truncated blades (fig. $5, n^{\circ} 4-5$ ) or blanks with a backed edge (fig. $5, n^{\circ} 2$ ). They have a rectilinear profile and present one or two natural sharp cutting edges used for three main fields of activity: carcass processing, skin working and plant working.

The first domain probably includes several distinct technical operations. On a macroscopic scale, the tools present wear comparable with discreet bifacial chipping, initiated by flexure or more rarely in cones, at grazing to semi-abrupt angles, spaced out or overlapping, with a length of less than $2 \mathrm{~mm}$. On the other hand, observation with a metallographic microscope leads to the distinction of two types of traces. 
Table 4 - Domestic tools from the upper Peyrazet sequence

\begin{tabular}{|lrrrrr|}
\hline \multicolumn{1}{|c}{ TYPES } & LAME & LAMELLE & ECLAT & ELL & \multicolumn{1}{c|}{ NR } \\
\hline couteau \& fgt & 15 & & & 5 & $\mathbf{2 0}$ \\
grattoir & 5 & 4 & 1 & $\mathbf{1 0}$ \\
lame retouchée \& fgt & 6 & & & & $\mathbf{6}$ \\
burin & 5 & & & $\mathbf{5}$ \\
pièce esquillée \& fgt & 1 & & 2 & $\mathbf{5}$ \\
lame tronquée & 4 & & & $\mathbf{4}$ \\
microperçoir & 2 & & 1 & $\mathbf{3}$ \\
couteau à dos & 1 & & & $\mathbf{1}$ \\
pièce tronquée & & 1 & & 1 \\
grattoir-burin & & 1 & & & $\mathbf{1}$ \\
lamelle tronquée & & 1 & $\mathbf{8}$ & $\mathbf{9}$ & $\mathbf{5 7}$ \\
\hline NR & $\mathbf{3 9}$ & 13 & & 23 & $\mathbf{3 6}$ \\
\hline chute de burin & & &
\end{tabular}

Figure 5 - Domestic tools (1,7,10: burins; 2 : backed knives; 3,8,9: end scrapers; 4-5: truncated blades; 6 : blade with inverse chipping; Drawings $C$. Fat Cheung, Use-wear information MTA: soft animal materials).
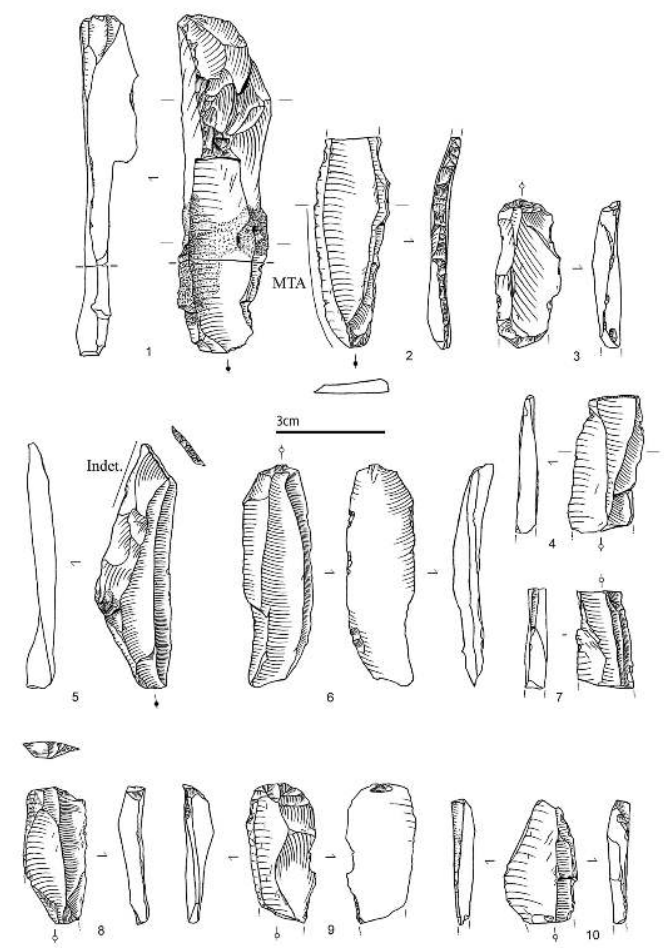
Figure 6 - Domestic tools (1: splintered piece; 2,3: end scrapers; 4: truncated piece; Drawings C. Fat Cheung).

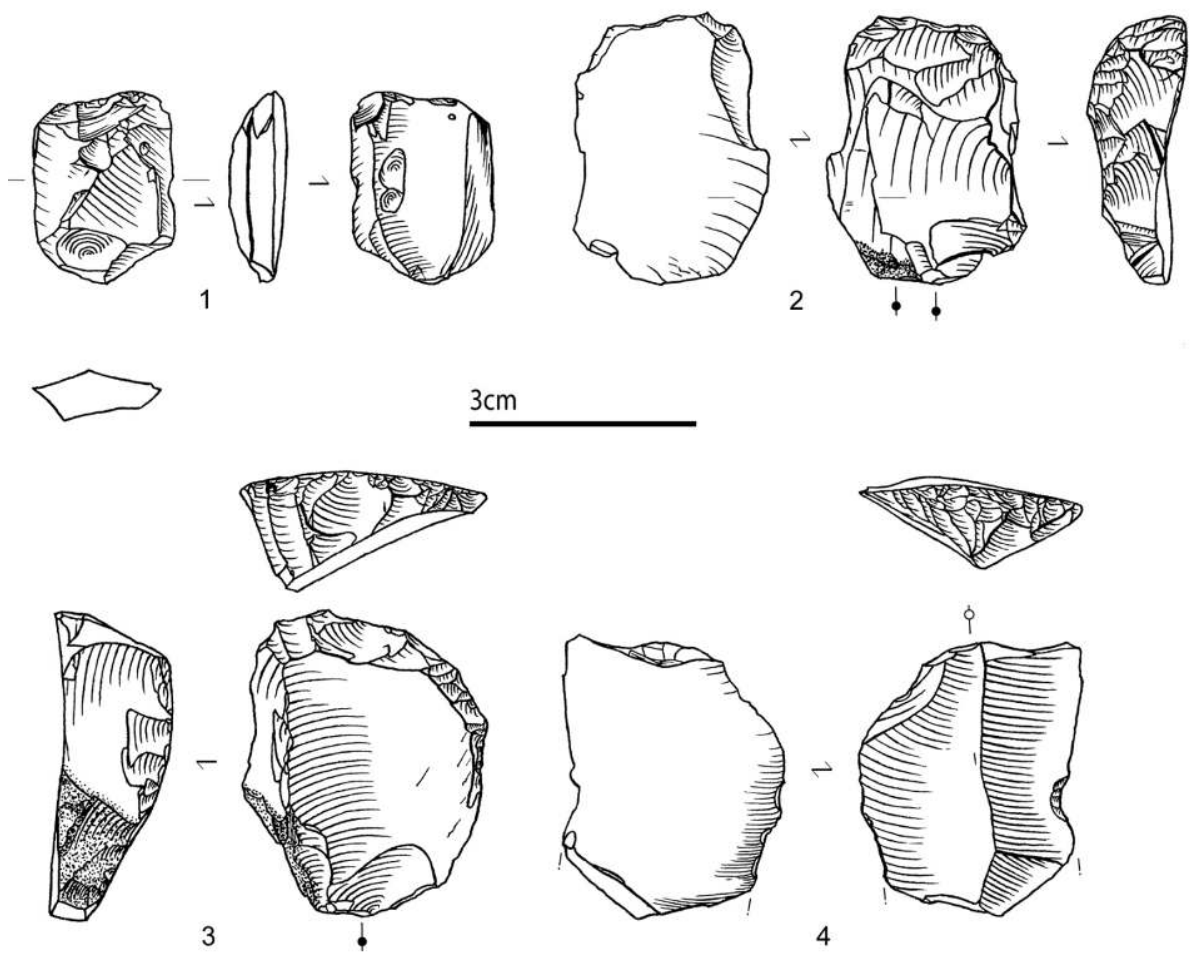

Some of the observed use wear is compatible with the butchery or defleshing stages. The microwear evokes contact with meat. The working edge presents a smooth and shiny, discontinuous micro-rounded edge, which is imperceptible with a stereomicroscope. This sometimes also affects the base of the usewear removal scars. It extends onto the surfaces as a fluid and shiny marginal micropolish, with soft coalescences in places. Several rare fine and discreet striations, parallel to the edge, accompany this microwear (fig. 8, $\mathrm{n}^{\circ} 1-2$ ).

The other usewear is much more developed and results from longitudinal contacts with what appear to be more resistant materials. However, the type of material has not been identified (tendons, guts, fresh or humid skin?). Macroscopically, the rounding of the working edge is already perceptible. The micropolish spreads more extensively onto the surfaces and tends to soften the peaks of the microtopography. The aspect of the polished zones is grainy but with relatively pronounced shininess. The fine and parallel striations on the edge are more abundant (fig. 8, $n^{\circ} 3$ ).

The traces of skin working observed on the non-retouched edges display wide diversity. Scraping operations are predominant. Some of the usewear is very similar to wear on end scraper arcs and attests to dry skin working activities. This is the case in particular for a piece with two used angular zones (fig. $9, \mathrm{n}^{\circ} 3$ ) and a blade with usewear on the left edge (fig. $9, \mathrm{n}^{\circ} 2$ ). Other sharp non-retouched edges seem to have been used to work humid skin. Edge rounding is less pronounced, the polish extends into the deepest parts of removal scars resulting from use, it is shinier and does not necessarily present a grainy aspect. Striations are not generally frequent. The usewear in the category of fresh hide working comprises disparate micropolishes. Some of them affect both high and low zones of the microtopography without clearly modifying the topography (fluid 
polishes), except in some isolated areas near the edge where the pattern can be softer and smoother (fig. 10, $\mathrm{n}^{\circ}$ 1). Other polishes, such as those on the cutting edge of a burin spall (fig. $10, n^{\circ} 2$ ), modify the microsurface more intensely.

Figure 7 - Laminar blanks with traces of use.

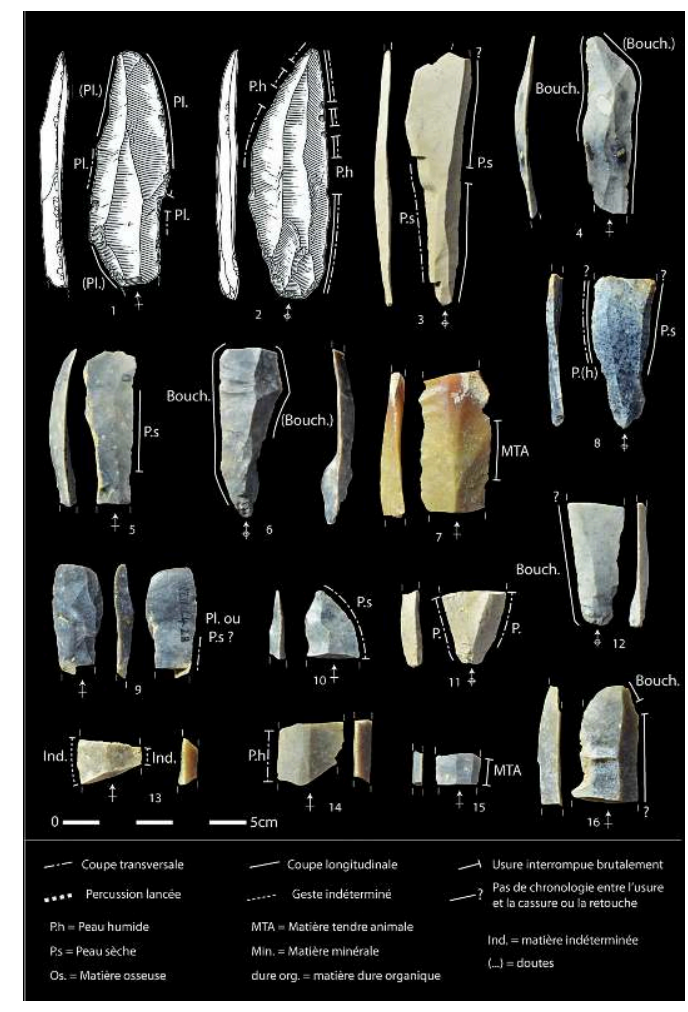


Figure 8 - Unmodified blanks used for defleshing and cutting soft animal materials. 1 and 2: fragments of laminar blanks with macro- and microscopic traces compatible with defleshing; 3 : proximal fragment of a burin spall with macro- and microscopic traces related to cutting unidentified soft animal matter.

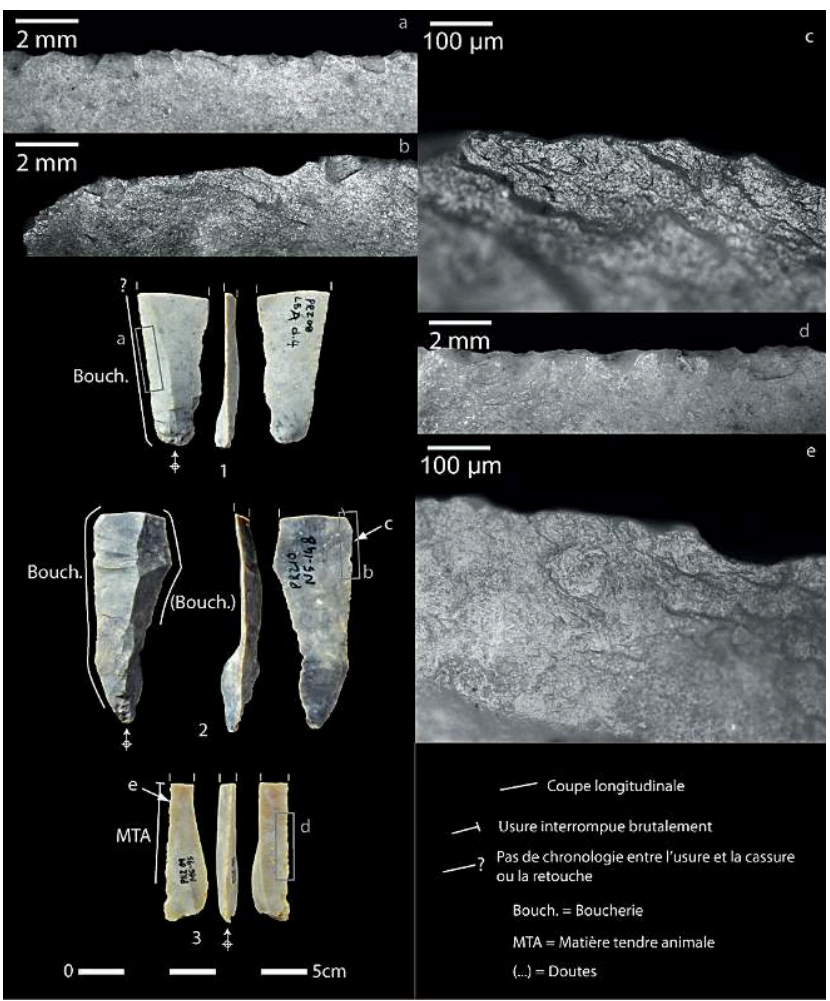


Figure 9 - 1 - End scraper with traces of dry skin scraping; 2: unretouched blade use to cut and scrape dry skins $\left(>90^{\circ}\right.$ working angle); 3 fragment of a probable laminar blank with traces attributed to dry hide scraping $\left(<90^{\circ}\right.$ working angle) on the pointed edges of the break.

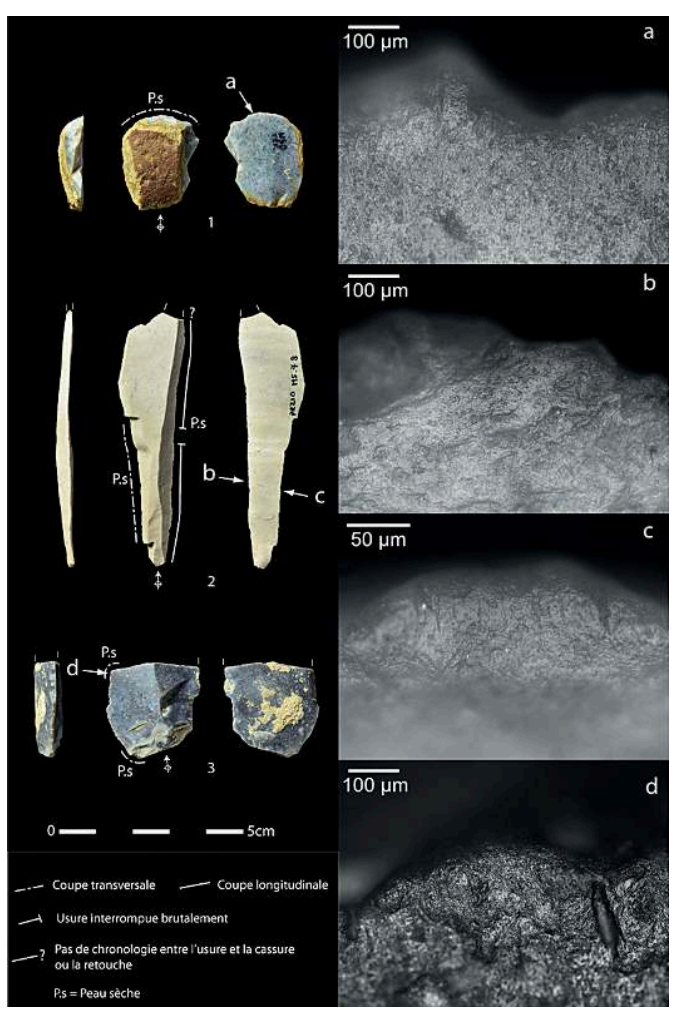


Figure 10 - Pieces used to work fresh skins. 1. distal fragment of an indeterminate blank with traces of fresh hide scraping interspersed with probable accidental chipping; 2 : mesial fragment of a burin spall with traces of fresh hide working; 3 : distal fragment of a burin spall with traces attributed to cutting fresh hide.

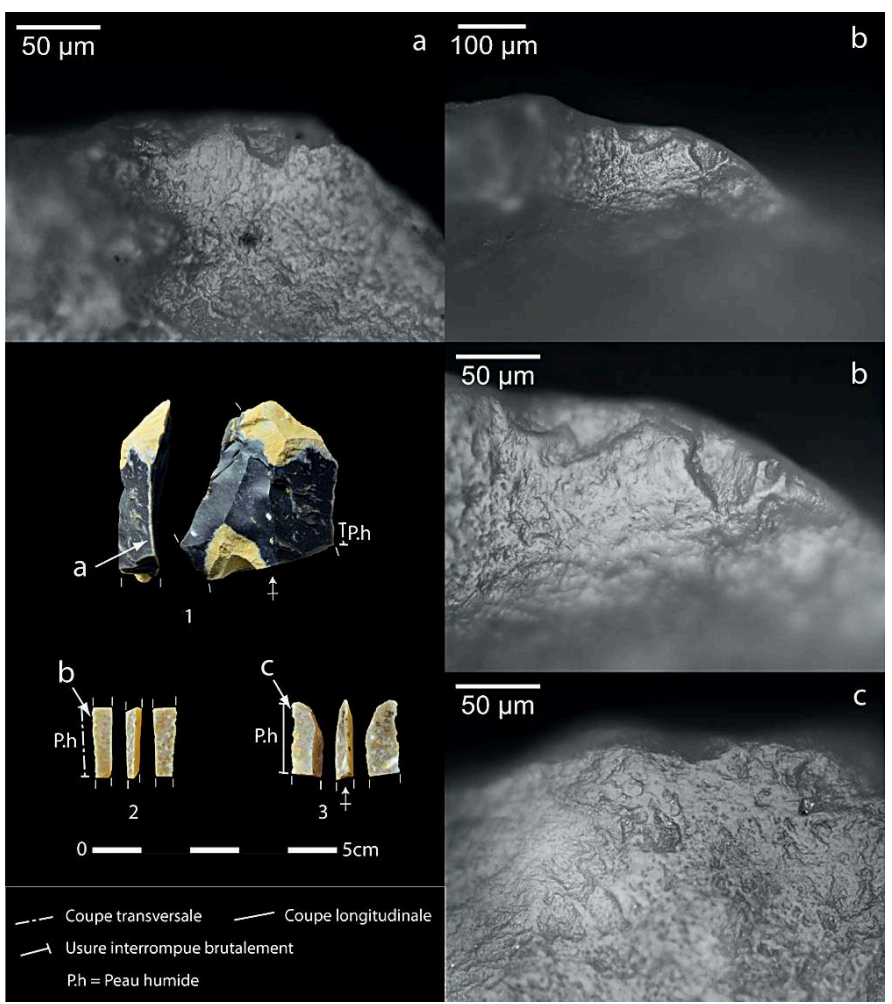

Figure 11 - Unretouched blade used with transverse (oblique $>90^{\circ}$ working angle) and longitudinal microwear resulting from use on a non-woody plant material.

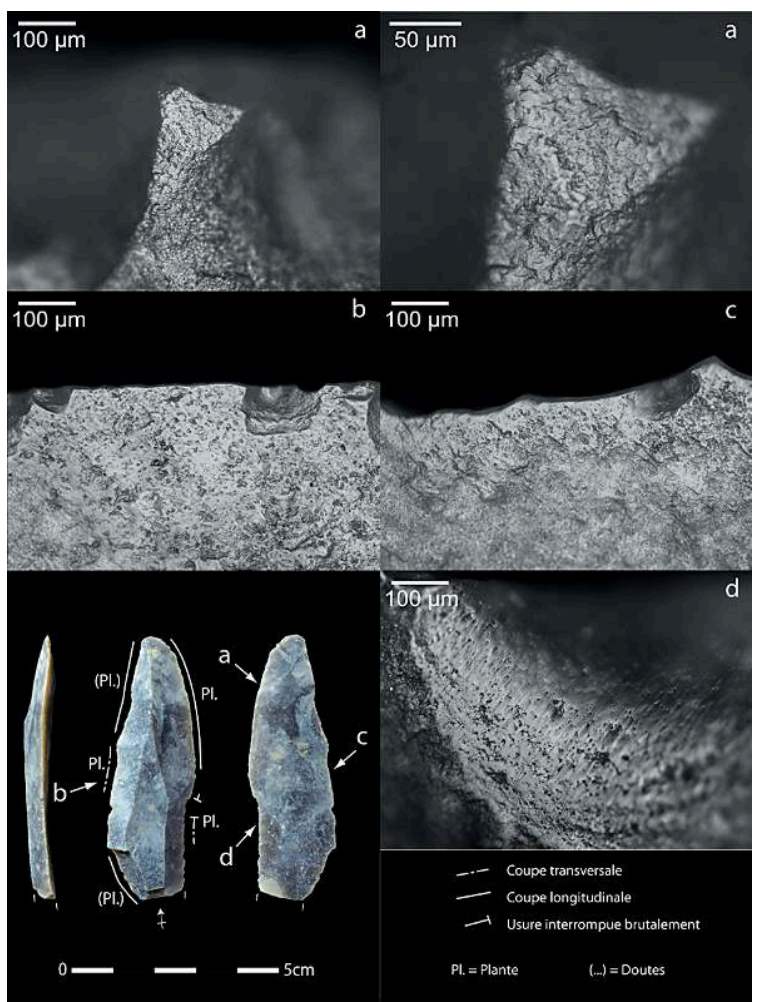


Plant working is only recorded by a single tool with five active zones (fig. 11). Two of these illustrate scraping motions and the three others are attributed to cutting actions. The first two ZU are short and affect two zones with slightly concave delineation. The edges present slight bifacial, spaced out chipping, which is more abundant on the edge in contact with the worked material. The chipping scars are mainly initiated by flexure with variable morphology in top view (mainly semi-circular to scalar). The microwear is clearly dissymmetric. On the surface in contact with the material, the edge is continuously rounded and smooth. This microwear gradually fades out on the surface and extends into a smooth and shiny invasive micropolish which mainly affects the higher zones. Striations are rare - except for a removal scar initiated by flexure on ZU 2 - but the extension of the polish clearly indicates an oblique motion. On the opposite face, the rounded edge is visible but extremely limited and restricted to the edge. It affects the surfaces and the hollows of the microtopography and has a "soft" aspect. Striations are absent but like on the other surface, an oblique extension is perceptible. Similar usewear was identified in several assemblages from the Recent Dryas / Preboreal transition in north-western France (Jacquier 2014; ongoing PhD). This usewear is also very similar to that described on numerous tools from the Mesolithic (Juel Jensen 1994; Beugnier 2007; Guéret 2013). The worked materials appear to be nonwoody plants. These tools could be linked to basket-making activities.

The end scrapers are made on blades from the full debitage phase and on lamellar flakes or flakes retrieved from knapping waste (fig. 5, $\mathrm{n}^{\circ} 3,8-9$; fig. 6, $\mathrm{n}^{\circ} 2-3$ ). Like in most archaeological contexts, the end scrapers from Peyrazet are used for skin processing. One of the tools presents traces of scraping mineral materials on the lateral edge but this use precedes the retouch on the end scraper arc. Four end scrapers were used for scraping dry hide. Edge rounding is quite well developed and is visible at low optical magnifications. It seems to cover the lower surface of the blank more extensively than the upper surface, indicating a low angle between this surface and the worked material. They are always more or less centred on the arc. The micropolish is very similar from one arc to another and is characterized by a slight gloss, a grainy and irregular aspect due to the presence of abundant plucked out matter (fig. 9, $n^{\circ} 1$ ). No evidence of hafting has been observed but it is difficult to envisage the efficient use of such small tools without hafting.

Two pièces esquillées (or wedges) present marks resulting from percussion on organic matter. These are a whole thick flake and a mesial fragment of a laminar blank (fig. 12). They appear to have been used as intermediary tools during percussion operations on hard materials. They present two zones marked by intense macroscopic wear on opposite ends of the blank. The usewear is characterized by overlapping large-sized abrupt chipping. Some pieces bear burin-type accidents along the edges. The damaged zones are sometimes deeply fissured but do not bear crushing or abrasion indicative of contact with mineral matter. No microscopic traces enable us to discern the type of hard organic materials in contact with the tool. The function of these elements is thus difficult to assess.

Two of the five burins from the series present usewear on the parts exposed by the extraction on the spalls. Both were used on an indeterminate osseous material. The dihedral burin was used for grooving and the other was used for scraping (fig. 13). The observed usewear is typical of working hard animal materials. The robust edges present small Hertzian trapezoidal chipping with abrupt extremities. The active edges bear a 
discontinuous flat microscopic bevel, extending perpendicularly to the edge. A band of shiny micropolish with a characteristic soft aspect extends over the surfaces in contact with the worked material (fig. 13). The analysis of the burins and the spalls also shows that the original blanks were used as knives in varied operations before being transformed into burins: butchery (fig. 8, $\mathrm{n}^{\circ}$ 3), working fresh or dry skins (fig. 10, nos 2-3; fig. 14), working mineral matter (fig. 13, $\mathrm{n}^{\circ} 1$ ).

\section{The armatures}

The Laborian armatures from Peyrazet comprise 90 elements, as well as five waste elements or rough outs (tab. 5). Three main groups can be distinguished: narrow backed points (cf. Blanchères; Rozoy 1978); truncated backed points and bi-truncated backed points (cf. "Malaurie" and "rectangles") and trapezoid bi-truncations. The presence of a curved backed point on a backed bladelet with an inversely sharpened point indicates, in our opinion, mixing with the underlying levels.

51 The three types of armatures correspond to different models. The bi-truncations are almost identical. For the backed points, although the length can only rarely be assessed due to fragmentation, the few whole Blanchères type pieces measure between $22 \mathrm{~mm}$ and $37 \mathrm{~mm}$ long and the rare whole Malaurie type points measure about $35-40 \mathrm{~mm}$. The first group presents lengths ranging between 3 and $7 \mathrm{~mm}$ (centred around $5 \mathrm{~mm}$ ) and thicknesses of 1-2 mm, while the second shows greater width variability, between 8 and $13 \mathrm{~mm}$, and thickness variability, between 2 and $4 \mathrm{~mm}$.

Figure 12 - Pièces esquillées (splintered pieces or wedges) with percussion traces due to contact with a probable hard organic material using direct and indirect percussion.

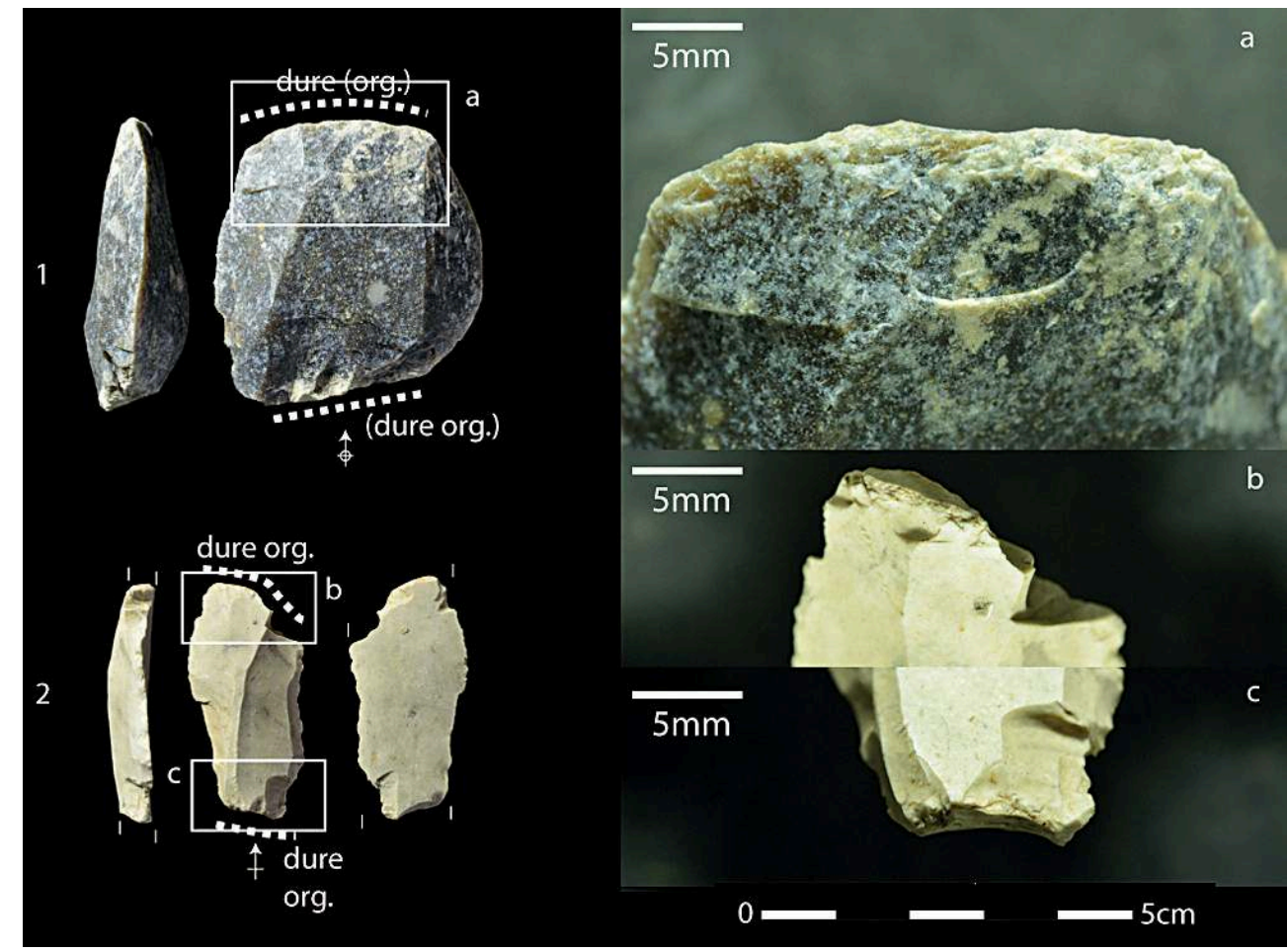


Table 5 - Microlith counts for the upper Peyrazet sequence (PL: small blade, ELL: bladelet, fgt: fragment, LD: backed bladelet).

\begin{tabular}{|lrrrr|}
\hline \multicolumn{1}{|c}{ TYPES } & LAMELLE & PETITE LAME & ELL & NR \\
\hline fgt LD/PD étroite & 30 & 1 & 1 & $\mathbf{3 2}$ \\
PD étroite \& fgt & 17 & 1 & $\mathbf{1 8}$ \\
Pointe des Blanchères \& fgt & 17 & 1 & $\mathbf{1 8}$ \\
Pointe de Malaurie \& fgt & 1 & 15 & $\mathbf{1 6}$ \\
bitronqué rectangle & 1 & 1 & $\mathbf{2}$ \\
bitronqué trapéziforme & & 2 & $\mathbf{2}$ \\
PD courbe & 1 & & 1 & $\mathbf{1}$ \\
LD appointée inverse & $\mathbf{6 7}$ & $\mathbf{2 1}$ & $\mathbf{2}$ & $\mathbf{9 0}$ \\
\hline NR & 3 & & & $\mathbf{3}$ \\
\hline ébauche LD/PD & & 1 & 1 & $\mathbf{2}$ \\
déchet fabrication LD/PD & & & \\
\hline
\end{tabular}

52 The group of narrow armatures includes 68 pieces (fig. 15, $\mathrm{n}^{\circ}$ 1-6). The pointed elements do not indicate preferential lateralization of the backs, which are equally often on the right (9 cases) or the left (9 cases).

53 On the other hand, the point is more often proximal. A Blanchères type point presents a burin type removal of about $2 \mathrm{~mm}$ long, beginning at the base and running along the cutting edge. It could have been made by repercussion after the impact. Towards the apex, the cutting edge also presents a series of scalar oblique chipping towards the base which is compatible with the use of a perforating element on a projectile weapon (fig. 15).

Figure 13 - Tools used to work osseous materials. 1: dihedral burin used to groove an unidentified osseous material that also bears traces of scraping a mineral material; 2 possible burin on break used to scrape an unidentified osseous material.

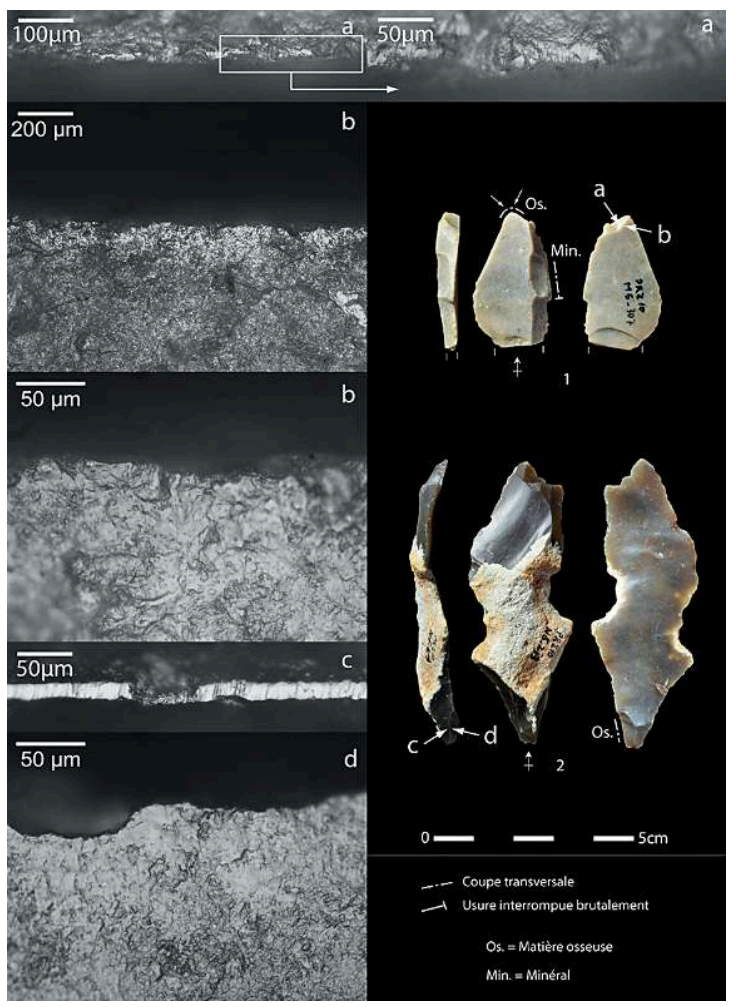


Figure 14 - Burins and burin spalls with use-wear traces.

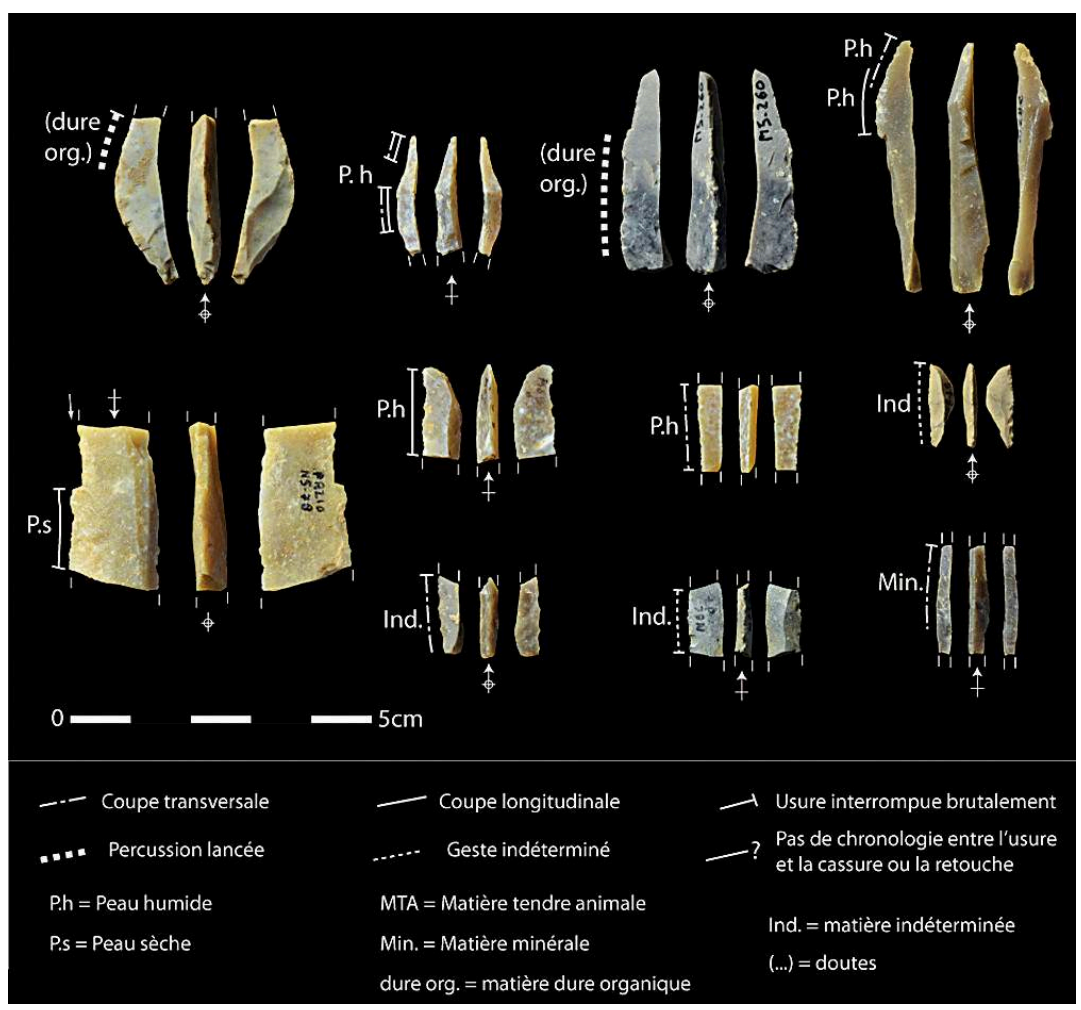

The truncated backed points (Malaurie) and the bi-truncated backed rectangles on small blades comprise 18 elements (fig. 16). The point is frequently on the distal part and the backs can be on the right (13 cases) or on the left side (8 cases). Two refitted elements, corresponding to a fragment of a backed point and truncated Malaurie-type base (fig. 16, $n^{\circ} 6$ ), present ambiguous damage. The three breaks are initiated by flexure and bear splines of slightly less than $2 \mathrm{~mm}$ with abrupt ends. The base also presents a wide inverse chip. No MLIT (Microscopic Linear Impact Traces; Odell 1978) were identified. The breaks were not really diagnosed as they are too short but the fact that they are associated with the removal at the base - potentially created during a repercussion impact - could support the hypothesis of use as a projectile weapon. Diagnostic impact marks were identified on three other Malaurie-type points. The first (fig. 16, $\mathrm{n}^{\circ} 1$ ) bears a bending fracture with a spline of over $10 \mathrm{~mm}$. The two others (fig. $16, \mathrm{n}^{\circ} 7,5 ; 1$ and 2) present straight breaks without splines with spin-off type chipping of about $2 \mathrm{~mm}$. Impact striations accompany this damage on one of the two tools (fig. 16, 2b). The observed MLIT on these elements are generally oriented along the technological axis of the objects. They are sometimes slightly oblique but enable us to confirm that these elements were used for perforating parallel to the shafts. The only studied rectangle (fig. 16, $\mathrm{n}^{\circ}$ 8) did not bear any diagnostic use wear traces. Technological observations of other series suggest that these backed bitruncations may correspond to the recycling of Malaurie type points (Langlais 2007; Langlais et al. 2014b). Are they systematically issued from such a process? What is the aim of this transformation? Once they were transformed, were they used in the hunting sphere or in other functional domains? It will be necessary to undertake the techno-functional analysis of new series in order to reply to these questions but this hypothesis would explain their variable presence at the different sites. 
Figure 15 - 1-6: Straight-backed Blanchères points and fragments. A: oblique chipping on the ventral surface of an edge near the point, $B$ : burin-type removal fracture beginning at the base; $7-8$ : Trapezoid bi-truncations (Drawing S. Ducasse).

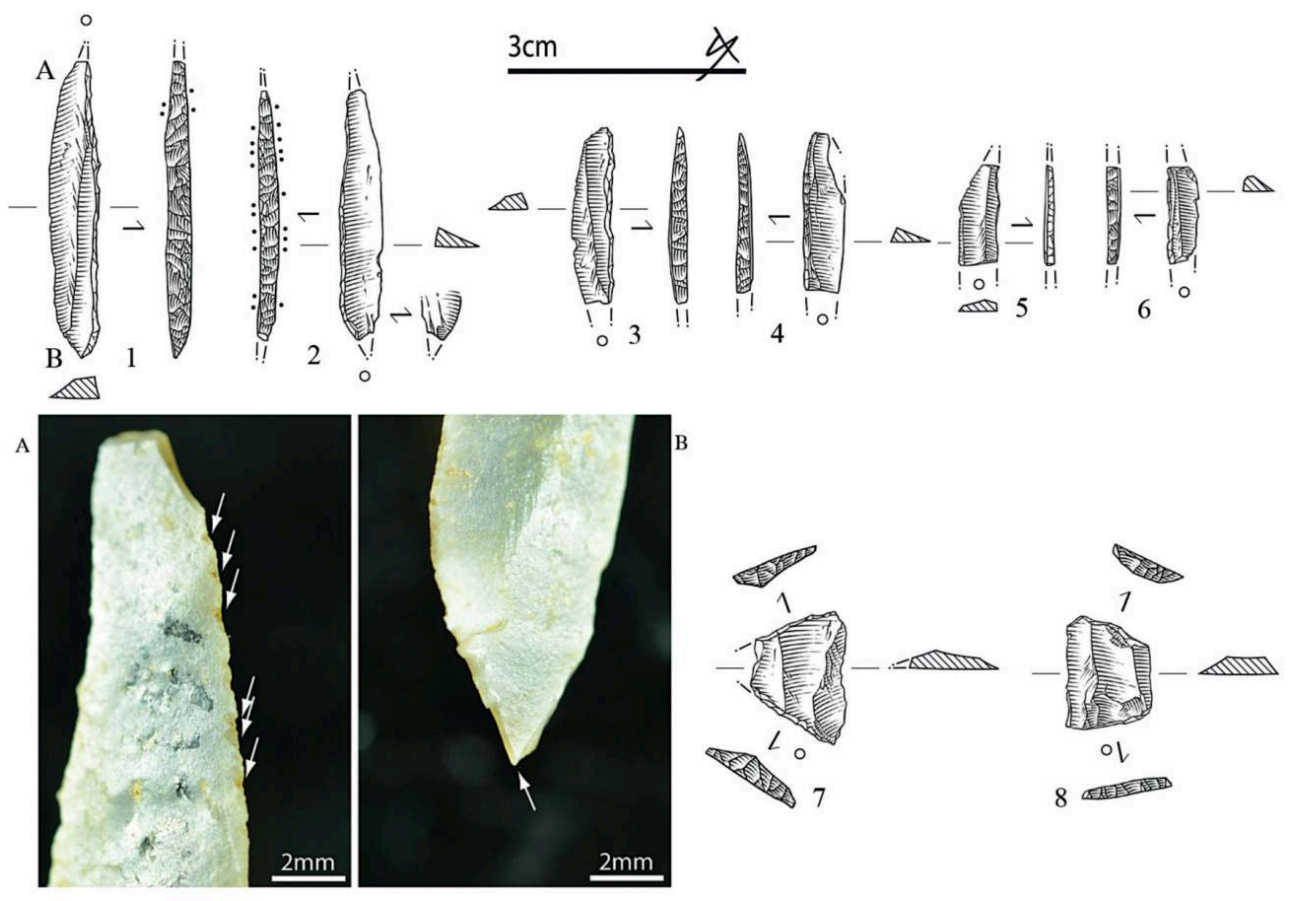

Trapezoid bi-truncations $(\mathrm{N}=2)$ correspond to segments of small blades truncated at both ends delimiting two cutting trapeze bases. We did not note any preferential lateralization of the truncations or bases (fig. 15, $\mathrm{n}^{\circ} 7-8$ ). The analysis of these two elements did not yield any indication of their role in the technical system. For now, the function of these tools thus remains poorly understood. Observations of other series only yielded rare indications of the use of these elements. The macro and microscopic observation of most of the trapezoid bi-truncations from the site of La Fosse in Mayenne did not provide any evidence pointing to the use of this tool as a knife, but on the other hand, two damaged pieces point to the use of these elements as projectile heads mounted as a cutting armature (Naudinot 2013, fig. 2; Jacquier PhD in progress). A specimen from La Borie del Rey c. 3 could also provide further evidence of this type of use (Langlais et al. 2014b, fig. 19).

\section{Blade-bladelet production methods}

The multiple fragments and flakes (tab. 3) mostly come from blade-bladelet productions (bars, making crests and correcting the sides...). They supply blanks for extra tools, particularly for end scrapers (fig. 6, $n^{\circ} 2-3$ ). These observations also apply to the laminar flakes retrieved from knapping waste. Shaping blades (ribbing) and core maintenance blades are also retrieved from debitage conducted in the cave as blanks for tools (burins, retouched knives and blades). The aim of laminar production is to supply regular blades with rectilinear profiles transformed into end tools (burins, end scrapers; fig. 5) or used as knives (fig. 7). Continuing on from laminar debitage, or even separately using smaller volumes, small blades were transformed into truncated 
backed (Malaurie) and bi-truncated backed pieces (rectangles), but also into trapezoid bi-truncations and more rarely into domestic tools (truncation, microborer).

Figure 16 -Truncated-backed Malaurie points (nos 1-7) and a bi-truncated backed rectangle $\left(\mathrm{n}^{\circ} 8\right)$ from the upper Peyrazet sequence (Drawings S. Ducasse) ; Diagnostic impact fractures 1: straight bending fracture and spin-offs on the ventral surface $\left(n^{\circ} 7\right) ; 2 a$ : straight bending fracture with a single spin-off on the ventral surface, $2 b$ : linear impact striations $\left(n^{\circ} 5\right)$.
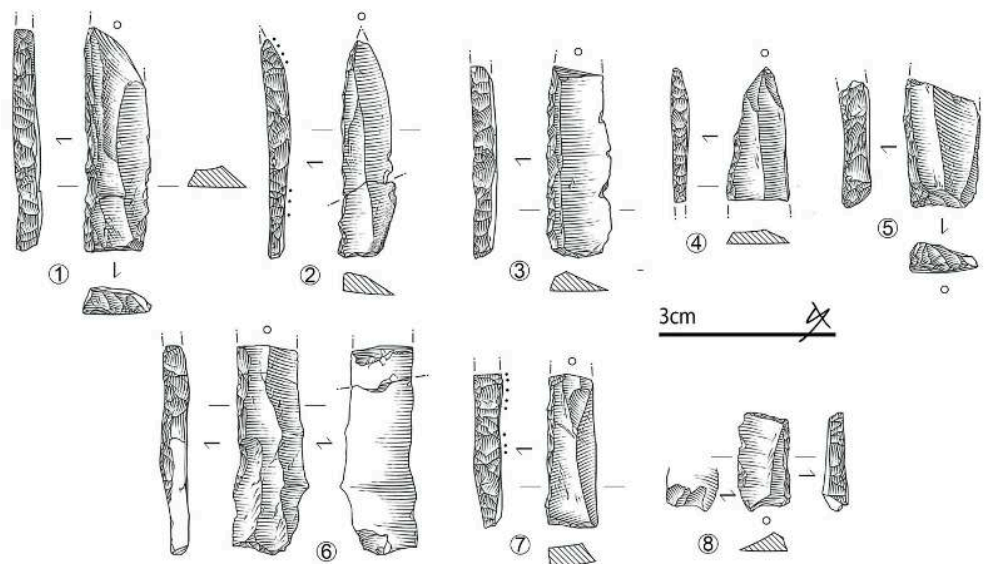

(7)

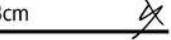

$x$
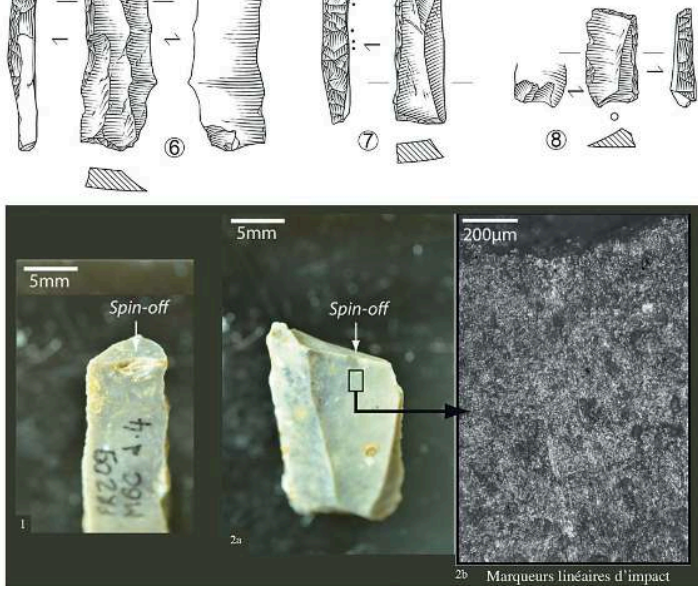

Figure 17 - Blade-bladelet cores (Drawings S. Ducasse).

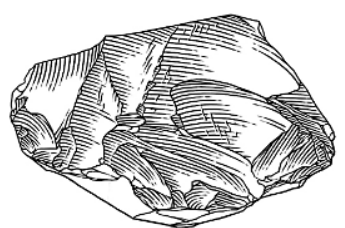

1

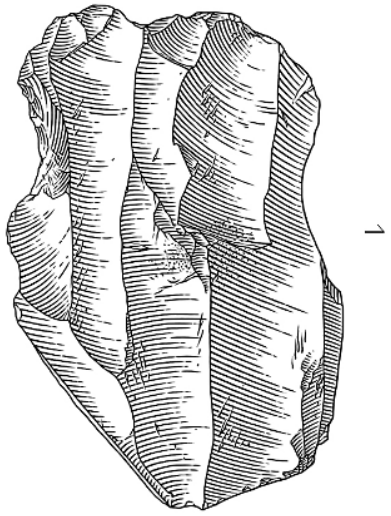

(1)

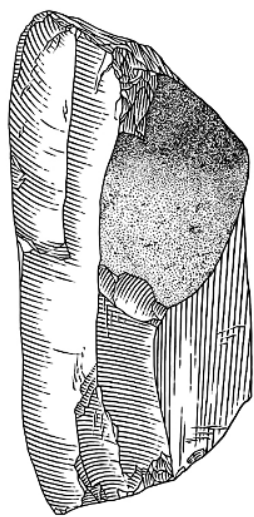

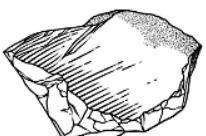

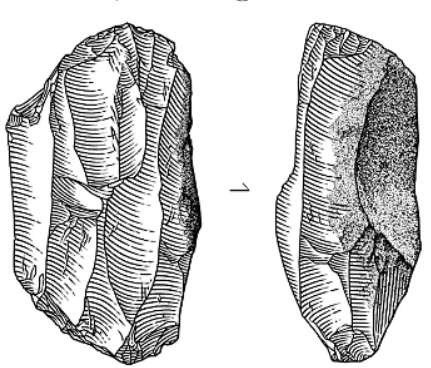

$3 \mathrm{~cm}$ 媇 
The presence of blanks with bipolar removal scars from the shaping phase and the full debitage phase indicates the use of two opposite striking platforms. This is also visible on the two cores from the series (fig. 17). The succession of unipolar sequences intersected by sporadic cleaning is visible on either plan. This principle points to the production of regular and flat blanks. In addition, the use of a stone hammer throughout the debitage contributes to the success of this aim, which results in frequent resolved flakes which then require refreshing. In parallel, transverse removals maintain the volume of the core and create favorable conditions for the debitage of regular and rectilinear blanks. In this way, recourse to localized neocrests is very frequent $(\mathrm{N}=22)$. Preparation for the removal of blades and bladelets consists of relatively strong abrasion in order to favour the extraction of stone blanks, mainly tangentially.

The bladelets are extracted from small blades or independently from small nodules (particularly jasperoids), and present the same technical characteristics as the blades as far as their regularity and rectilinear profile are concerned. They nonetheless indicate a higher rate of removal scar unipolarity which could indicate the abandonment of one of the striking platforms or less need to clean from a second striking platform as the available length would be easier to manage from a single pole. Most of these bladelets were intended for use as lighter backed points (cf. Blanchères).

The continuum of laminar and lamellar templates (between 20 and $5 \mathrm{~mm}$ wide and 1 to $3 \mathrm{~mm}$ thick) and their technical homogeneity incite us to advance the hypothesis of a conceptual lamino-lamellar continuum. According to the diverse intrinsic qualities and the initial dimensions of the available volumes for debitage, this sequence could have been carried out on the same volume. The attribution of this technically homogeneous assemblage to a precise phase of the Laborian/Épilaborian is difficult as we now know that they are very similar (Langlais et al. 2014b, fig. 34-35), apart from the types of armatures (see below) and a higher lamellar component for the latter (Naudinot 2013). 
Figure 18 - Le vestige en ocre de Peyrazet. Figure 18 - Ochre piece from Peyrazet.

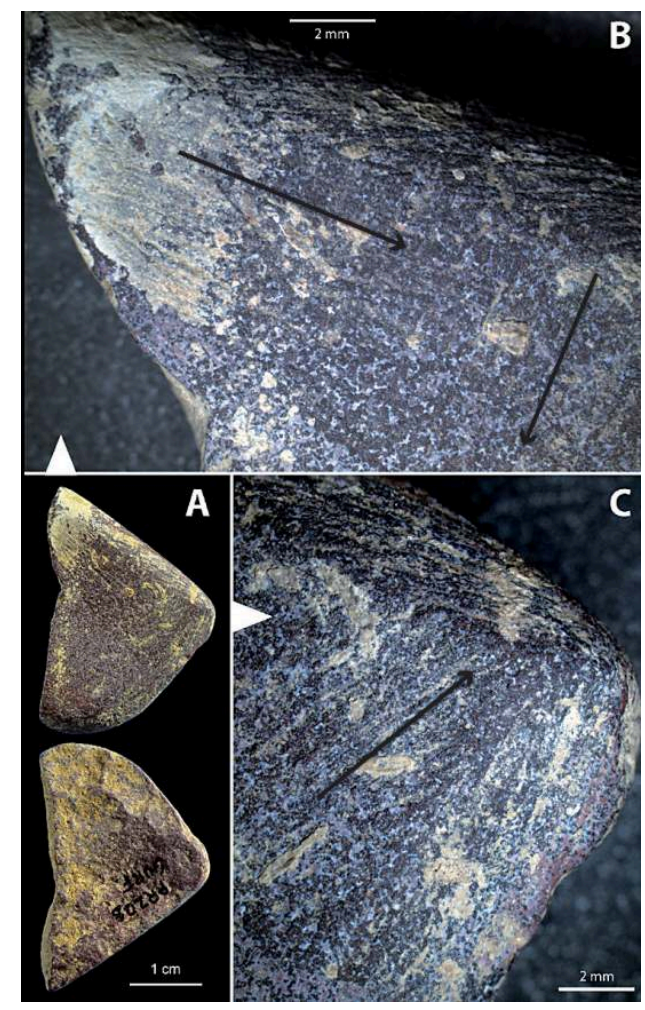

\section{The "ochre pencil" from Peyrazet: remnant of powder production or an intentionally made object?}

A fragment of red ferruginous rock with clear abrasion marks was found out of stratigraphic context. The attribution of this object remains problematic but due to its position on the surface in a sector where the upper level is exposed, we consider that it belongs to the Laborian toolkit. This object is rather unusual as it presents four striated facets, with one wide, almost triangular surface (fig. 18A). The raw material is a ferruginous argillite type rock, composed of kaolinite and hematite (according to X-ray diffraction analysis). From a morphological viewpoint, we can refer to it as a "pencil" (with convergent facets), although it presents a tabular aspect and narrow sides. The striations totally cover the main surface, one of the sides and part of the second side. They are fine and parallel, and the facets are plane to plano-convex, indicating abrasion against a mineral (no scraping marks).The third side corresponds to a former fracture, presenting a possible impact mark on the upper striated surface. The chronology of the marks is difficult to establish due to the presence of numerous concretions. Two abrasion directions are observed on the triangular surface: they follow the direction of the two crests on either side of the point (fig. 18B), giving the surface a symmetrical aspect.

61 Facetted tabular objects have already been described in the literature (Soressi and d'Errico 2007; Salomon 2009; Watts 2010; Rifkin 2011; Dayet et al. 2013; Hodgskiss 2013). However, the fine sides, the two abrasion directions observed on a very plain main surface and the position of the fracture distinguish this object from the facetted pieces generally produced during the process of reduction into powder. These characteristics 
of the point (fig. 18C), as well as the position of the fracture, contradict the hypothesis of the use of this object as a "pencil" for marking surfaces (Salomon 2009). Some objects with use marks on the sides could be interpreted as lissoirs. This would be consistent with our observations. Another hypothesis is that the shape was the final aim. The fine surfaces evoke the morphology of certain stone pendants from Tardiglacial contexts (Rousseau 1933, pl. 5). This type of object is rare in the southwest of France.

\section{Personal ornaments}

The upper layers yielded four tusk shell tests and five nacre fragments. In order to identify the origin of the tusk shells and to verify if the hunter-gatherers selected and modified these objects, a morphometric and microscopic analysis was carried out. The tusk shells from Peyrazet were compared to two reference collections - a modern collection comprising 339 Dentalium vulgare collected on the beaches of Arcachon Basin and a fossil collection of 244 Dentalium sp. from the Miocene falun of Saucats (Vanhaeren 2002). The measurements recorded on the natural archaeological tusk shells include the length of the objects and the diameter of their openings. Some rare post-depositional modifications are present on the objects from Peyrazet, including several dissolution pits on the surface. One of the tusk shells presents a longitudinal break. The whole tusk shells from the reference collections present a slightly curved conical shape and a length ranging between 7 and 12 times their maximum diameter (Poppe and Goto 1993). The measurements recorded on the archaeological tusk shells show that two of them present lengths inferior to the minimal lengths obtained on the objects from the reference collections. The two others lie within the variability of the lengths recorded in the comparative reference collections. The length/diameter ratio of the four archaeological tusk shells varies between 1 and 3 . These results indicate that the objects found at Peyrazet do not lie within the metric variability of the two reference collections.

The anterior non-fractured openings of the natural tusk shells present a diameter of around $1 \mathrm{~mm}$. The measurements from Peyrazet show that the fore part of one object is present while the others are wider than $2.5 \mathrm{~mm}$. This indicates that three of the archaeological objects are portions from the central or rear part of the shells, and that the finer fore part is absent. For the reference collections, the openings of the intact tusk shells present fine and sharp edges, perpendicular to the shell axis (Vanhaeren 2002). This is only observed on one of objects (fig. 19d). The other ends of the tusk shells present clear edges intercepting the cylinder of the shell perpendicularly (fig. 19). This is observed on certain natural breaks or after fracturing by flexure (ibid.). 
Figure 19 - Dentalium: a, c - proximal extremity; b, $d$ - distal extremity; e - wear; $f$ - the fragment is too short to identify the proximal and distal extremities.

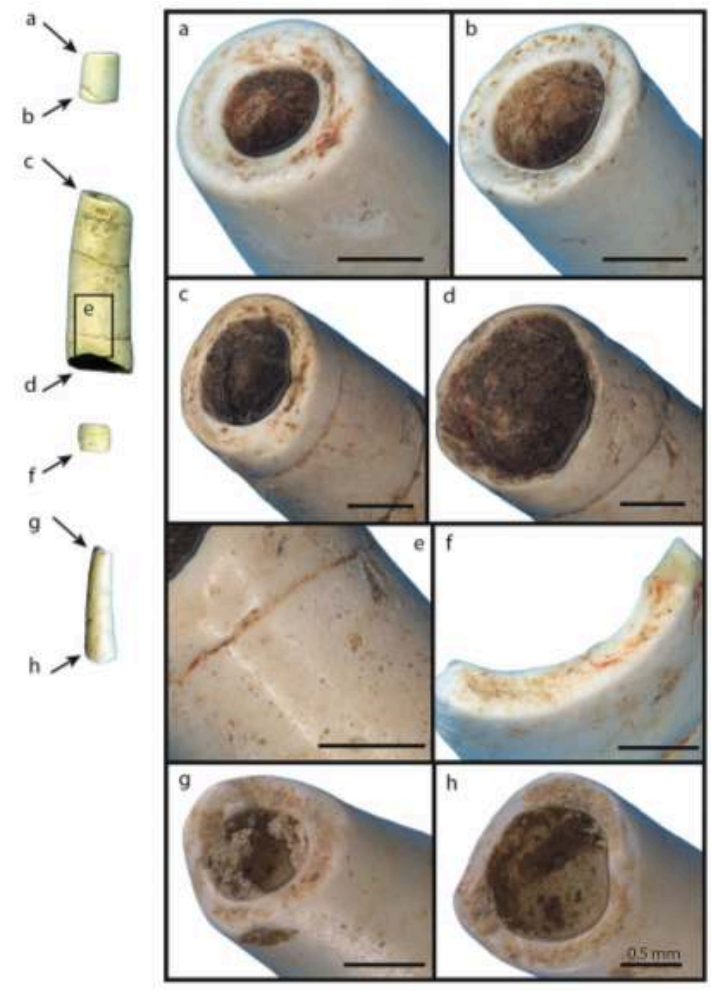
inter-stratigraphic mixing, due in particular to the presence of one or more burrows 
and to different post-depositional processes. These processes could explain the intrusive presence of several reindeer remains, two Azilian and Magdalenian lithic armatures and the rare potsherds recovered from the upper complex. Apart from this pollution, which is frequent in cave infillings, this upper complex provides new elements for the knowledge of the Laborian complex in the region and its surroundings and on the type of activities carried out in the cave.

The attribution to this chrono-cultural complex is mainly based on the composition of the lithic toolkit (careful production of rectilinear blades with stone hammers, backed points with post-Azilian characteristics; Naudinot 2010; Langlais et al. 2014a).

As for the type of Laborian occupations of the site, several points can be underlined. We observed the introduction of pebbles (possibly for combustion) and different volumes and blanks in siliceous materials for making and maintaining equipment for domestic and hunting activities. Most of this comes from a radius of $50 \mathrm{~km}$ around the site and in particular from the grey-black Senonian deposits. The introduction of whole or partial animal carcasses (mainly red deer) was followed by butchery and several technical operations linked to skin removal and hide processing. Hide working is the best documented activity at the site. The identification of fresh or humid skin scraping suggests that the early stages of the operational sequence took place at Peyrazet. Dry hide working and in particular, scraping hide with angular and cutting edges points to the final finishing stages and making objects in hide. We also noted the production of blanks and tools in hard animal matter and the application of debitage by longitudinal grooving. Personal ornaments were brought to the site as tusk shell tests. The use of colorants is also represented by a shaped object and the probable use of lithic blanks linked to the scraping of mineral matter. The working of non-woody plants could be related to basket-making.

The hare is occasionally exploited at Peyrazet but the preferred game of the Laborian groups is the red deer.

This choice is similar to that of layer 3 at La Borie del Rey and level 2 of Port-de-Penne (Langlais et al. 2014b). On the other hand, in other known Laborian sites - Le Pont d'Ambon c.2 in Dordogne (Célérier (dir.) 1994; Gilbert 1984), La Borie del Rey c.7 and c.5 in Lot-et-Garonne (Langlais et al. 2014b), Manirac in the Gers (Gilbert op. cit.) and Champ-Chalatras in Puy-de-Dôme (Pasty et al. 2002) - the aurochs is the main prey. Lastly, level 1 at Port-de-Penne yielded a spectrum dominated by the horse (Langlais et al. 2014b).

73 At Peyrazet, the environmental data from the different faunal remains point to a diversity of biotopes associating open landscapes (grasslands, steppe) with closed areas (scrub with coppices) and rocky zones. This reflects the location of the Peyrazet caveshelter at the interface between the alluvial plain, cliffs and the Causse plateau.

Due to the conditions of the deposition and the conservation of the archaeological deposits, it is difficult to advance the hypothesis of a residential site, as implied by the diversity of activities and the superposition of occupations with specific functions that change throughout time. It appears problematic to assess the socio-economic status of this/these occupations. The hypothesis of logistic installations related to hunting is difficult to back up in this context, unlike recent proposals for level 2 of the open-air site of Port-de-Penne in Agenais (Langlais et al. 2014b). 
Three 14C dates were carried out on red deer bone. The first (Ly7828/SacA22775, $9780 \pm$ 45 BP) places at least some of the Peyrazet occupations at the Pleistocene-Holocene transition, at about $11.5-11 \mathrm{Ky}$ cal. BP. For the other two (Ly9062/SacA28329, $9235 \pm 45$ BP; Ly11973/SacA40415, $8560 \pm 60 \mathrm{BP}$ ), the Lyon and Saclay laboratories note a low collagen content $(4 \mathrm{mg} / \mathrm{g}$ ) which tends to relativize these results. They appear to be too recent compared to those for the early regional Mesolithic (fig. 20, tab. 6).

In order to broach the question of the association of Malaurie points with Blanchères points and trapezoid bi-truncations in a Laborian complex, we need to broaden our comparisons to several sites (see also Naudinot 2010, tab. 4.1). This trio is also recorded at La Borie del Rey c. 3, and the Malaurie and Blanchères point combination is present at La Borie c. 7 and c. 5 and Blanchères (Rozoy 1978; Valentin 1995; Naudinot 2010; Langlais et al. 2014b.); two eponymous sites with complex stratigraphic conditions. At other sites, these two types of points appear to be mutually exclusive, such as at Cuze de Neussargues (Rozoy 1978; Delpuech et al. 1983), and Closeau (Bodu 2000; Teyssandier 2000). The presence of trapezoid bi-truncations at Peyrazet raises the question of the existence of intercultural links between the last Epipalaeolithic groups (Langlais et al. dir. 2014, fig. 21).

Figure 20 - Radiocarbon dates for sites with Malaurie points (in red) and/or trapezoid bi-truncations (in green), Early Sauveterrian (in purple).

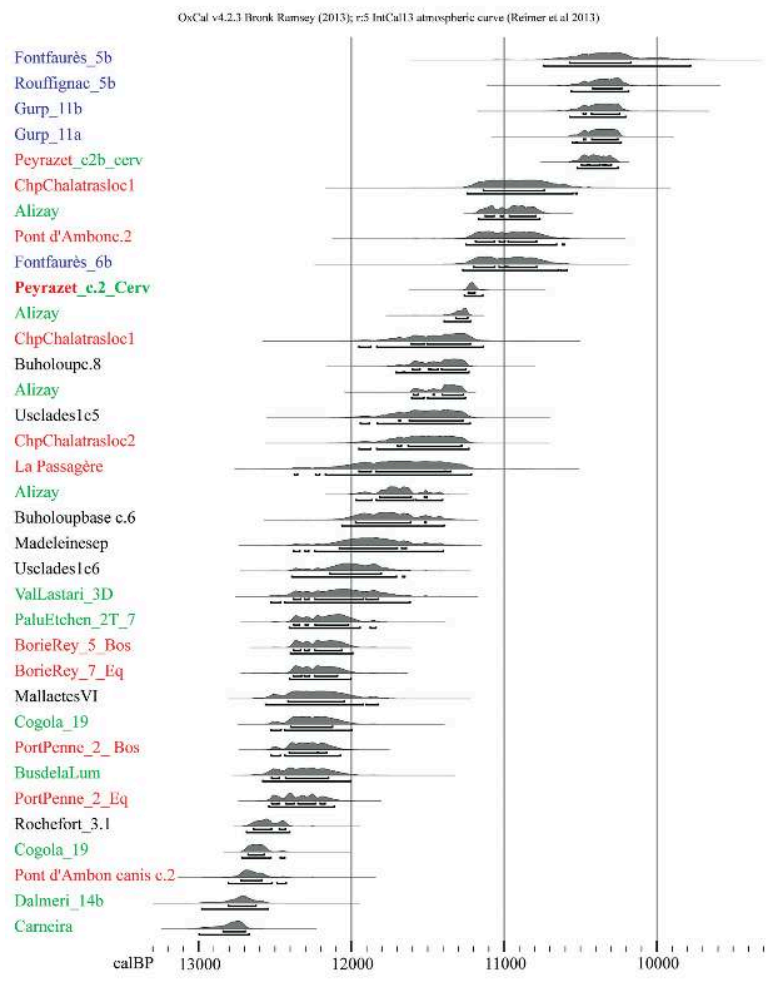


Table 6 - References for radiocarbon dates used in figure 36.

\begin{tabular}{|c|c|c|c|c|}
\hline SITE & DATE BP & ECART & CODE & REFERENCES \\
\hline Fontiaurds_5b & 9140 & 160 & Ly4448 & Barbaza et al. 1991 \\
\hline Rouffignax_5b & 9150 & 90 & GrN5514 & Bamiére 1974 \\
\hline Gurp_11b & 9180 & 90 & Ly5321 & Roussot-Larroque 2009 \\
\hline Gurp_11a & 9200 & 70 & Ly5322 & Roussot-Larroque 2009 \\
\hline Peyrazet_c2b_cerv & 9235 & 45 & Ly9062/SacA28329 & cet article \\
\hline ChpChalatras locl & 9580 & 140 & AA43089 & Pasty er al. 2002 \\
\hline Alizay & 9610 & 50 & Beta322721 & Bemilli er al. 2014 \\
\hline Pont đ'Ambon_c.2 & 9640 & 120 & Giß740 & Célérier 1998 \\
\hline Fonttaures $6 \mathrm{~b}$ & 9650 & 130 & Ly4449 & Barkaza et al. 1991 \\
\hline Peyrant_c__Cerv & 9780 & 45 & Ly $7828 \mathrm{SacA} 22775$ & Langlais ef al. $2014 \mathrm{~b}$ \\
\hline Alizay & 9890 & 40 & Beta317897 & Bemilli ef al. 2014 \\
\hline ChppChalatras_locl & 9920 & 120 & AA43083 & Pasty ef al. 20022 \\
\hline Buholoup_c.8 & 9952 & 69 & Ly1092 & Briois et Vaquer 20099 \\
\hline Alizay & 9960 & 40 & Beta333640 & Bemilliet al. 2014 \\
\hline Usclades 1 ef & 9990 & 100 & Gif8437 & Maury 1999 \\
\hline Chpc halatras 1002 & 100000 & 100 & AA43085 & Pasty ef al. 2002 \\
\hline La Passagere & 10080 & 150 & Ly 3647 & $\operatorname{Manin} 2000$ \\
\hline Alizay & 10100 & 40 & Beta333638 & Bemilliet al. 2014 \\
\hline Buholoup_base c.6 & 10131 & 78 & Ly1091 & Briois et Vaquer 20009 \\
\hline Madekine_síp & 10190) & 100 & GifA95457 & Gambier er al. 2000 \\
\hline Usclades__of & 10250 & 80 & Girß438 & Maury 1999 \\
\hline ValLastari_3D & 10280 & 110 & Uic 2685 & Peresani er al. 2000 \\
\hline PaluEtchen_2T_7 & 10320 & 60) & UtCl 3428 & Mussi, Peresani 2011 \\
\hline BorieRey_5_Bos & 10340 & 50 & Ly-SacA28803 & Langlais ef al. $2014 \mathrm{~b}$ \\
\hline BorieRey_ 7 Eq & 10350 & 50 & Ly-SacA28804 & Langlais ef al. $2014 \mathrm{~b}$ \\
\hline Mallactes VI & 10370 & 105 & Knl915 & Fonka 1973 \\
\hline Cogola_19 & 10380 & 70 & URC 286 & Peresani ex al. 2000 \\
\hline PortPenne_2_ Bos & 10410 & 50 & Ly-SacA28801 & Langlais ef at. $2014 \mathrm{~b}$ \\
\hline BusdelaLum & 10430 & 90 & Uic8912 & Peresani ef al. 2000 \\
\hline PortPenne_2 Eq & 10440 & 50 & Ly-SacA28802 & Langlais ef at. 2014b \\
\hline Rochefort_ 3.1 & 10570 & 60 & GrA30689 & Hinguant, Colleter 2005 \\
\hline Cogola_19 & 10640 & 60 & Uic9287 & Peresani et al, 20000 \\
\hline Pont d'Ambon_canis_c.2.2 & 10730 & 100 & GifA99102 & Célénier et al. 19999 \\
\hline Gavel_af_charb & 10760 & 190 & Gif2654 & Sacchi 1986 \\
\hline Dalmeri $14 \mathrm{~b}$ & 10800 & 110 & R425 & Mussi, Peresani 2011 \\
\hline Cameira & 10880 & 90 & SMU2535 & Zilhao 1997 \\
\hline
\end{tabular}

77 Indeed, these armatures point to links with Aquitaine (ibid.), the north of the Loire (Naudinot 2010, 2013) and the east of the Rhône (Peresani et al. 2000; Duches et al. 2014). These objects (which must not be mixed up with the microlithic trapezes from the second Mesolithic) are also present in Aquitaine in difficult stratigraphic contexts: La Borie del Rey c. 3, Roc d'Abeille mixed with the early Azilian (Champagne \& Espitalié 1970), at Roquemissou in a complex with microgravette points (Bobœuf 2003), at Moulin du Roc (Detrain et al. 1996) or Gare de Couze, "associated" with the Upper Magdalenian (Bordes and Fitte1964). To the north of the Loire, trapezoid bi-truncations are associated with Blanchères points, like at Camp d'Auvours and Fosse (Naudinot and Jacquier 2009; Naudinot 2013). It is thus clear that the upper complex from Peyrazet raises new questions as to the continuation of the Malaurie point during the Recent Laborian/Epilaborian.

In conclusion, the recent Laborian complex from Peyrazet records diverse domestic and hunting activities in a cave-shelter context in a region where this cultural complex was poorly known up until now. More generally, this series is part of the debate on the European mosaic of cultural groups from the Pleistocene - Holocene transition. It contributes to questions concerning the rhythms of evolution of the lithic contents of quivers and the socio-economic organization of human groups during this period. 
Figure 21 - Epilaborian trapazoidal bitruncations (Couze, after Bordes and Fitte 1964; Moulin du Roc, Dordogne, after Detrain et al.1996, La Borie del Rey, Lot-et-Garonne, Drawings C. Fat Cheung), "Epilaboro-Ahrensbourgian" (La Fosse, Mayenne, after Naudinot and Jacquier 2009) and Epigravettian (Palu Etchen, Italy, after Duches et al. 2014).
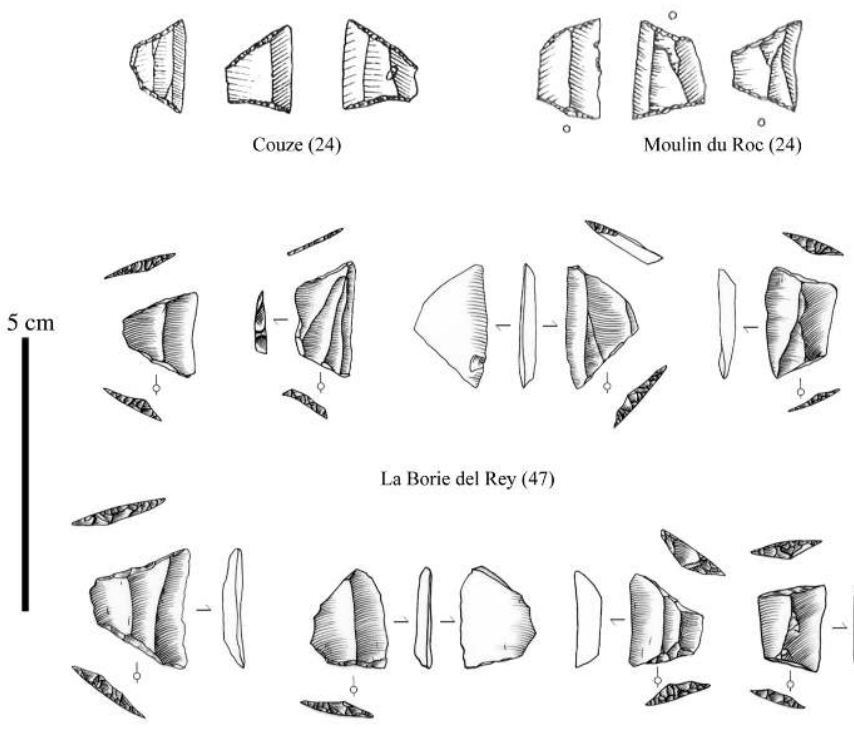

La Borie del Rey (47)
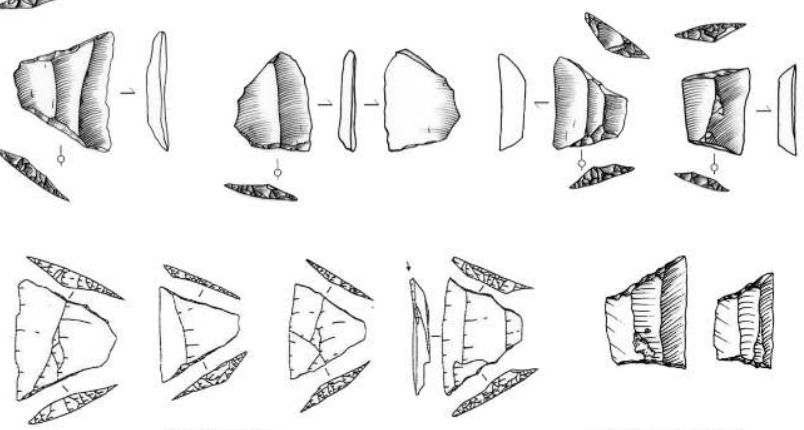

La Fosse (53)

Palu Etchen (Italie)

\section{BIBLIOGRAPHY}

BARBAZA M., VADEYRON N., ANDRE J., BRIOIS F., MARTIN H., PHILIBERT S., ALLIOS D., LIGNON E. 1991 - Fontfaurès en Quercy, contribution à l'étude du Sauveterrien, Toulouse, Archives d'Ecologie Préhistorique, 11, $271 \mathrm{p}$.

BARRIÈRE C. 1973-74 - Rouffignac. L'archéologie. Travaux de l'institut d'Art Préhistorique, université de Toulouse le Mirail, 15, p. 65-160;16, p. 3-47; 17, p. 3-83.

BEMILLI C., BIARD M., CHAUSSE C., DONNART K. 2014 - Une partie de chasse à l'Aurochs, il y a 10000 ans. Le Locus 28704 d'Alizay (Eure, France). In : S. Costamagno (dir.) : Histoire de l'alimentation humaine : entre choix et contraintes, actes du 138e congrés des Sociétés historiques et scientifiques, Rennes avril 2013, Paris, Ed. Du CTHS, p. 170-187.

BERTRAN P. 2004 - Dépôts de pente continentaux: Dynamiques et faciès. Quaternaire Hors-Série (1). Paris, Maison de la géologie, 258 p.

BEUGNIER V. 2007 - Préhistoire du travail des plantes dans le nord de la Belgique. Le cas du Mésolithique ancien et du Néolithique final en Flandre, in V. Beugnier, P. Crombe (dir.), Plant Processing from a Prehistoric and Ethnographic Perspective. Proceedings of a workshop at Ghent University 
(Belgium) November 28, 2006, Oxford, British Archaeological Reports, Archaeopress (BAR International Series 1718), p. 23-40

BODU P. 2000 - Les faciès tardiglaciaires à grandes lames rectilignes et les ensembles à pointes de Malaurie dans le sud du Bassin parisien : quelques réflexions à partir de l'exemple du gisement du Closeau (Hauts-de-Seine), in P. Crotti (dir.), Epipaléolithique et Mésolithique « Méso 97 », actes de la table ronde de Lausanne, novembre 1997, Cahiers d'archéologie romande 81, p. 9-28.

BORDES F. et FITTE P. 1964 - Microlithes du Magdalénien supérieur de la gare de Couze (Dordogne). In Miscelanea en homenaje al abate Henri Breuil, Instituto de Prehistoria y Arqueologia, Barcelona, p. 259-267.

BRIOIS F. et VAQUER J. 2009 - L'abri de Buholoup, de l'Epipaléolithique au Néolithique ancien dans le piémont central des Pyrénées, in Collectif, De la Méditerranée et d'ailleurs, Mélanges offerts à Jean Guilaine, Archives d'Ecologie Préhistorique, Toulouse, p. 141-149.

CAUX S. 2014 - A new piece within a larger puzzle: characterisation of 'grain de mil' flint from the Charente-Maritime, a central resource for the reconstruction of Palaeolithic territories in southwestern France. In A. Garcia, J. Garcia, A. Maximiano, J. Rios-Garaizar (ed.), Debating spatial archaeology, international workshop, Santander, juin 2012, IIIPC Ed., p. 143-152.

CÉLÉRIER G. dir. 1994 - L'abri-sous-roche de Pont d'Ambon à Bourdeilles (Dordogne). Le milieu biologique. Gallia Préhistoire, 36, p. 96-106.

CÉLÉRIER G. 1996 - L'abri-sous-roche de Pont d'Ambon à Bourdeilles (Dordogne). L'industrie osseuse et la parure. Gallia Préhistoire, 38, p. 69-110.

CÉLÉRIER G. 1998 - L'abri sous roche de Pont d'Ambon à Bourdeilles (Dordogne). Perspective synthétique. Paleo 10, p. 233-264.

CÉLÉRIER G., TISNERAT N., VALLADAS H. 1999 - Données nouvelles sur l'âge des vestiges de chien à Pont d'Ambon, Bourdeilles (Dordogne), Paleo 11, p. 163-165.

CHAMPAGNE F., ESPITALIE R. 1970 - L'abri du Roc d'Abeilles à Calviac (Dordogne), Gallia Préhistoire 13, p. 1-23.

COCHARD D. 2004 - Les léporidés dans la subsistance paléolithique du Sud de la France, Université Bordeaux 1, $354 \mathrm{p}$.

COSTAMAGNO S., LAROULANDIE V., LANGLAIS M., COCHARD D. 2009 - Exploitation du monde animal sur le versant nord des Pyrénées durant le Tardiglaciaire. In J.M. Fullola, N. Valdeyron et M. Langlais (dir.), Els Pirineus i les àrees circumdants durant el Tardiglacial. Mutacions i filiacions tecnoculturals evolucion paleoambiental, Actes du XIVe Colloque international d'Archéologie de Puigcerdà, Hommage à G. Laplace, novembre 2006, p. 185-209.

COULONGES L. 1963 - Magdalénien et périgordien post-glaciaires : la grotte de La Borie del Rey (Lot-et-Garonne), Gallia Préhistoire 7, p. 1-29.

DAYET L., TEXIER P.-J., DANIEL F., PORRAZ G. 2013 - Ochre resources from the Middle Stone Age sequence of Diepkloof Rock Shelter, Western Cape, South Africa. Journal of Archaeological Science, 40,9, p. 3492-3505.

DELPUECH A., FERNANDES P., RAYNAL J.-P., PAQUEREAU M.-M., DAUGAS J.-P. 1983 - Eléments de chronostratigraphie pour les niveaux épipaléolithiques du Cuze de Neussargues (Cantal), Bull. Soc. Préhist. Fr. 80 (4), p. 100-102.

DETRAIN L., GUILLON M. ; KERVAZO B., MADELEINE S., MORALA A., TURQ A. 1996 - Le Moulin du Roc à Saint-Chamassy (Dordogne). Résultats préliminaires. Bull. Soc. Préhist. Fr., 93 (1), p. 43-48. 
DRUCKER D.G., MADELAINE S., MORALA A. 2011 - Les derniers rennes de Dordogne : nouvelles données chronologiques et environnementales par l'étude isotopique du collagène $\left({ }^{13} \mathrm{C},{ }^{14} \mathrm{C}\right.$ et $\left.{ }^{15} \mathrm{~N}\right)$, Paleo 22, p. 85-100

DUCHES R., AVANZINI M., BASSETTI M., FLOR E., NERI S., DALMERI G. 2014 - Évolution de la mobilité épigravettienne durant le Dryas récent : quelles nouvelles informations pour l'Italie nord-orientale. In $\mathrm{M}$. Langlais, N. Naudinot, M. Peresani (dir.), Les groupes culturels de la transition Pléistocène - Holocène entre Atlantique et Adriatique, Table-ronde de Bordeaux, mai 2012, Séances de la SPF, vol. 3 , p. 185-204

FORTEA J. 1973 - Los complejos microlaminares y geometricos del Epipaleolitico mediterr.neo espanol. Memorias del Seminario de Prehist. y Arqueologia 4, 550 p.

GASSIN B. 1996 - Évolution socio-économique dans le Chasséen de la grotte de l'Église supérieure (Var). Apport de l'analyse fonctionnelle des industries lithiques, Paris, CNRS (Monographie du CRA, 17), 328 p.

GILBERT A. 1984 - Contribution à l'étude des faunes de la fin des temps glaciaires et au début des temps postglaciaires, thèse de doctorat, université de Bordeaux 1, $322 \mathrm{p}$.

GUÉRET C. 2013 - Identité et variabilité de l'outillage lithique du Premier Mésolithique en Belgique et dans le Nord de la France. Les apports de l'approche fonctionnelle, in B. Valentin, T. Ducrocq, J.-P. Fagnart, F. Seara, B. Souffi, C. Verjux (dir.), Palethnographie du Mésolithique : recherches sur les habitats de plein air entre Loire et Neckar, séances de la SPF, vol. 2, novembre 2010, Paris, p. 147-167.

HENRY-GAMBIER D., VALLADAS H., TISNERAT-LABORDE N., ARNOLD M., BESSON F. 2000 Datation de vestiges humains présumés du Paléolithique supérieur par la méthode du carbone 14 en spectrométrie de masse par accélérateur. Paleo 12, p. 201-212.

HERNANDEZ FERNANDEZ M. 2001 - Bioclimatic discriminant capacity of terrestrial mammal faunas. Global Ecology and Biogeography, 10, 2, p. 189-204.

HERNANDEZ FERNANDEZ M. 2006 - Rodent paleofaunas as indicators of climatic change in Europe during the last 125,000 years. Quaternary Research, 65 (2), p. 308-323.

HERNANDEZ FERNANDEZ M., PELAEZ-CAMPOMANES P. 2003 - The bioclimatic model: a method of palaeoclimatic qualitative inference based on mammal associations. Global Ecology and Biogeography, 12 (6), p. 507-517.

HERNANDEZ FERNANDEZ M., PELAEZ-CAMPOMANES P. 2005 - Quantitative palaeoclimatic inference based on terrestrial mammal faunas. Global Ecology and Biogeography, 14, 1, p. 39-56.

HODGSKISS T. 2013 - Ochre use in the Middle Stone Age at Sibudu, South Africa: grinding, rubbing, scoring and engraving. Journal of African Archaeology, 11, 1 p. 75-95.

JACQUIER J. 2014 - Analyse fonctionnelle des outillages lithiques et interprétations socioéconomique du statut des sites tardiglaciaires du Buhot à Calleville (Eure) et de la Fosse à VilliersCharlemagne (Mayenne), In : M. Langlais, N. Naudinot, M. Peresani (dir.), Les groupes culturels de la transition Pléistocène - Holocène entre Atlantique et Adriatique, Table-ronde de Bordeaux, mai 2012, Séances de la SPF, vol. 3, p. 221-246.

JEANNET M. 2010 - L'écologie quantifiée. Essai de description de l'environnement continental à l'aide des microvertébrés. Préhistoires Méditerranéennes, 1, p. 11-34.

JUEL JENSEN H. 1994 - Flint tools and plant working. Hidden traces of stone age technology. A use wear study of some danish mesolithic and TRB implements, Aarhus, University Press, 263 p. 
LANGLAIS M. 2007 - Dynamiques culturelles des sociétés magdaléniennes dans leurs cadres environnementaux. Enquête sur 7000 ans d'évolution de leurs industries lithiques entre Rhône et Èbre. Thèse de doctorat en cotutelle avec les universités de Toulouse-Le Mirail et Barcelone, 550 p.

LANGLAIS M., LAROULANDIE V. avec la collaboration de BRUXELLES L., CHALARD P., COCHARD D., COSTAMAGNO S., DELFOUR G., KUNTZ D., LE GALL O., PETILLON J.-M., QUEFFELEC A. 2009 - Les fouilles de la grotte-abri de Peyrazet (Creysse, Lot) : nouvelles données pour le Tardiglaciaire quercinois. Bull. Soc. Préhist. Fr. 106 (1), p. 150-152.

LANGLAIS M., NAUDINOT N. et PERESANI M. dir. 2014 - Les groupes culturels de la transition Pléistocène - Holocène entre Atlantique et Adriatique, Séance de la SPF, Bordeaux, mai 2012, Séances de la SPF, vol. 3, 246 p.

LANGLAIS M., COSTAMAGNO S., LAROULANDIE V., PETILLON J.M., DISCAMPS E., MALLYE J.B., COCHARD D., KUNTZ D. 2012 - The evolution of Magdalenian societies in South-West France between 18,000 and 14,000 cal BP: Changing environments, changing tool kits. Quaternary International 272-273, p. 138-149.

LANGLAIS M., BONNET-JACQUEMENT P., DETRAIN L., VALDEYRON N. 2014a - Le Laborien : ultime sursaut technique du cycle évolutif paléolithique du Sud-Ouest de la France ? In S. Michel et N. Naudinot (org.), session G, in J. Jaubert, N. Fourment, P. Depaepe (dir.) Transitions, ruptures et continuités en Préhistoire, Actes du XXVIIe Congrès Préhistorique de France, Bordeaux-Les Eyzies, juin 2010, Mémoire de la SPF, p. 417-430.

LANGLAIS M., DETRAIN L., FERRIÉ J.-G., MALLYE J.-B., MARQUEBIELLE B., RIGAUD S., TURQ A., BONNET-JACQUEMENT P., BOUDADI-MALIGNE M., CAUX S., FAT CHEUNG C., NAUDINOT N., MORALA A., VALDEYRON N., CHAUVIÈRE F.-X. 2014b - Réévaluation des gisements de La Borie del Rey et de Port-de-Penne : nouvelles perspectives pour la transition Pléistocène - Holocène dans le sud-ouest de la France ; in M. Langlais, N. Naudinot, M. Peresani (dir.), Les groupes culturels de la transition Pléistocène - Holocène entre Atlantique et Adriatique, Table-ronde de Bordeaux, mai 2012, Séances de la SPF, vol. 3, p. 83-128.

LE LOUARN H. et QUÉRÉ J.-P. 2003 - Les rongeurs de France : faunistique et biologie. Editions Quae, $260 \mathrm{p}$.

LENOBLE A. 2005 - Ruissellement et formation des sites préhistoriques : référentiel actualiste et exemples d'application au fossile. Archaeopress BAR, Oxford, $216 \mathrm{p}$.

LE TENSORER J.M. 1981 - Le Paléolithique de l'Agenais, Cahiers du Quaternaire 3, CNRS, 526 p.

LLOVERAS L., MORENO GARCIA M., NADAL J. 2009 - Butchery, Cooking and Human Consumption Marks on Rabbit (Oryctolagus cuniculus) Bones: An experimental Study, Journal of Taphonomy 7 , 179-201.

LORBLANCHET M. 1972 - Aperçu sur le Magdalénien moyen et supérieur du Haut-Quercy. In : CPF, XIXe session, Auvergne, 1969, Soc. Préhist. Fr., p. 256-283.

LORBLANCHET M. 1989 - Caractères originaux du Magdalénien du Quercy. In J.-P. Rigaud (dir.), Le Magdalénien en Europe, Colloque de Mayence, 1987, ERAUL 38, p. 239-252.

LORBLANCHET M. 1996 - Du Magdalénien à l'Azilien en Quercy. In La vie préhistorique, Ed. Faton, p. 282-285.

MALLYE J.-B. 2007 - Les restes de Blaireau en contexte archéologique : Taphonomie, archéozoologie et éléments de discussion des séquences préhistoriques. Thèse de Doctorat, Université Bordeaux 1, 547 p. 
MARQUET J.-C. 1993 - Paléoenvironnement et chronologie des sites du domaine Atlantique français d'âge Pléistocène moyen et supérieur d'après l'étude des rongeurs. Tours, Les Cahiers de la Claise, Supplément 2, $345 \mathrm{p}$.

MAURY J. 1999 - Le groupe épipaléolithique des Usclades (Nant, Aveyron), Bull. Soc. Préhist. Fr. 96 (4), p 505-528.

MONIN G. 2000 - Apport de la technologie lithique à l'étude de séries anciennes. Les assemblages tardiglaciaires des chasseurs de marmottes des grottes de Colomb et de la Passagère à Méaudre (Vercors, Isère), in G. Pion (Ed.), Le Paléolithique supérieur récent : nouvelles données sur le peuplement et l'environnement, Table ronde de Chambéry, 1999, Mém. SPF 28, p. 271-287.

MUSSI M., PERESANI M. 2011 - Human settlement of Italy during the Younger Dryas, Quaternary International 242; p. 360-370.

NAUDINOT N. 2010 - Dynamiques techno-économiques et de peuplement au Tardiglaciaire dans le GrandOuest de la France, thèse de doctorat, université Rennes 1, 735 p.

NAUDINOT N. 2013 - La fin du Tardiglaciaire dans le Grand-Ouest de la France. Bull. Soc. Préhist. Fr. 110 (2), p. 233-255.

NAUDINOT N., JACQUIER J. 2009 - Un site tardiglaciaire en place à la Fosse (Villiers-Charlemagne, Mayenne) : premiers résultats et implications chronoculturelles. Bull. Soc. Préhist. Fr. 106 (1), p. $145-149$.

NIEDERLANDER A., LACAM A., SONNEVILLE-BORDES D. de 1956 - L'abri Pagès à Rocamadour et la question de l'Azilien dans le Lot, L'Anthrop. 60 (5-6), p. 417-446.

ODELL G.-H. 1978 - Préliminaires d'une analyse fonctionnelle des pointes microlithiques de Bergumermeer (Pays-Bas), Bulletin de la Société Préhistorique Française 75 : p. 37-49.

PASTY J.F., ALIX Ph., BALLUT C., GRIGGO C., MURAT R. 2002 - Le gisement épipaléolithique à pointes de Malaurie de Champ-Chalatras (Les Martres d'Artière, Puy-de-Dôme), Paleo 14, p. 101-176.

PERESANI M., BERTOLA S., DE STEFANI M., DI ANASTASIO G. 2000 - Bus de la Lum and the Epigravettian occupation of the Venetian Pre-Alps during the Younger Dryas, Rivista di Scienze Preistoriche L, p. 103-132.

PLISSON H. 1985 - Étude fonctionnelle d'outillages lithiques préhistoriques par l'analyse des microusures : recherche méthodologique et archéologique, thèse de doctorat, université Paris 1 - PanthéonSorbonne, $353 \mathrm{p}$.

POPPE G.T., GOTO Y. 1993 - European Sea shells. (Scaphopoda, Bivalvia, Cephalopoda). Hemmen, Wiesbaden.

RIFKIN R.F. 2012 - Processing Ochre in the Middle Stone Age: Testing the Inference of Prehistoric Behaviours from Actualistically Derived Experimental Data. Journal of Anthropological Archaeology, 31, 2, p. 174-195.

ROUSSEAU L. 1933 - Le Magdalénien dans la Vienne. Découverte et fouille d'un gisement du Magdalénien à Angles-sur-l'Anglin (Vienne). Bull. Soc. Préhist. Fr., 30 (4), p. 239-256.

ROZOY J.G. 1978 - Les derniers chasseurs - L'Epipaléolithique en France et en Belgique - Essai de synthèse. Bull. Soc. Arch. Champ., 3 vol.

SEMENOV S. A. 1964 - Prehistoric Technology, an Experimental Study of the Oldest Tools and Artifacts from Traces of Manufacture and Wear, Londres, Cory, Adams and Mackay, $211 \mathrm{p}$. 
SÉRONIE-VIVIEN M.-R. dir. 2001 - La grotte du Sanglier à Reilhac (Lot). Du Magdalénien au Néolithique ancien, Préhistoire du Sud-Ouest, suppl.4, 182 p.

SÉRONIE-VIVIEN M.-R. dir. 1995 - La grotte de Pégourié, Caniac-du-Causse (Lot). PérigordienBadegoulien-Azilien-Age du Bronze, quercynoise, suppl. 2, 334 p.

SACCHI D. 1986 - Le Paléolithique supérieur du Languedoc occidental et du Roussillon. Gallia Préhistoire XXIe suppl., Ed. du CNRS, Paris, 284 p.

SALOMON H. 2009 - Les matières colorantes au début du Paléolithique supérieur : sources, transformations et fonctions. Université Bordeaux I, Thèse de doctorat, $427 \mathrm{p}$.

SIMONNET R. avec la collaboration de BON F., BORDES J.-G., PRIMAULT J. 2007 - Le silex « Grains de Mil ». Localisation des gîtes. In N. Cazals et X. Terradas (dir.), Frontières naturelles et frontières culturelles dans les Pyrénées préhistoriques, Table ronde de Tarascon/Ariège, 2004, Publican Ediciones universidad de Cantabria, Santander, p. 101-102.

SORESSI M., D'ERRICO F. 2007 - Pigments, gravures, parures : les comportements symboliques controversés des Néandertaliens, in B. Vandermeersch, B. Maureille (Eds.), Les Néandertaliens, biologie et cultures, Ed. CTHS, Documents préhistoriques 23, Paris, p. 297-309.

SZMIDT C., LAROULANDIE V., DACHARY M., LANGLAIS M., COSTAMAGNO S. 2009 - Harfang, Renne et Cerf : nouvelles dates ${ }^{14} \mathrm{C}$ par SMA du Magdalénien supérieur du Bassin aquitain au Morin (Gironde) et Bourrouilla (Pyrénées-Atlantiques). Bull. Soc. Préhist. Fr. 106 (3), p. 583-587.

TEYSSANDIER N. 2000 - Un gisement belloisien sur les bords de la Seine : le Closeau à RueilMalmaison (Hauts-de-Seine), Bull. Soc. Préhist. Fr. 97 (2), p. 211-228.

TURQ A. 2000 - Le Paléolithique inférieur et moyen entre les vallées de la Dordogne et du Lot. Paleo, supplément $\mathrm{n}^{\circ} 2$, avril 2000, $456 \mathrm{p}$.

TURQ A., MORALA A. avec la collaboration de M.-R. SERONIE-VIVIEN et M. SERONIE-VIVIEN 2014 - Inventaire des silicifications du Quercy, de ses marges et des marqueurs lithologiques du nordest aquitain : synthèse des données, in M. Jarry, J.P. Brugal, C. Ferrier (dir.), Modalités d'occupation et exploitation des milieux au Paléolithique dans le sud-ouest de la France : l'exemple du Quercy, suppl. Paleo $\mathrm{n}^{\circ} 4$, XVe congrès de l'IUSPP, Lisbonne, session C67, septembre 2006, p. 159-180.

VALDEYRON N., BOSC-ZANARDO B., BRIAND T., HENRY A., MARQUEBIELLE B., MICHEL S. 2011 - Le gisement du Cuzoul de Gramat (Lot, France) : présentation des nouveaux travaux et résultats préliminaires. Sénépart I., Perrin T., Thirault E., Bonnardin S. (dir.), Marges, frontières et transgressions. Actes des 8e Rencontres Méridionales de Préhistoire Récente, Marseille, novembre 2008, Archives d'Ecologie Préhistorique, Toulouse, p. 197-211.

VALENTIN B. 1995 - Les groupes humains et leurs traditions au Tardiglaciaire dans le Bassin parisien. Apports de la technologie lithique comparée, Thèse de Doctorat, université de Paris 1, 3 vol. , 1106 p.

VAN GIJN A. L. 1989 - The Wear and Tear of Flint: Principles of Functional Analysis Applied to Dutch Neolithic Assemblages, Leyde, University of Leiden, Institute of Prehistory (Analecta Praehistorica Leidensia, 22), $181 \mathrm{p}$.

VANHAEREN M. 2002 - Les fonctions de la parure au Paléolithique supérieur : de l'individu à l'unité culturelle. Thèse de doctorat, Université de Bordeaux 1, Talence.

VIGNE J.-D., MARINVAL-VIGNE M.-C. 1983 - Méthode pour la mise en évidence de la consommation du petit gibier, in Clutton-Brock J., Grigson C. (Eds.), Animals and Archaeology. 1 : Hunters and their prey, Archaeopress BAR, p. 239-242. 
VIGNE J.-D., MARINVAL-VIGNE M.-C., DE LANFRANCHI F., WEISS M.-C. 1981 - Consommation du «Lapin-rat » (Prolagus sardus Wagner) au Néolithique ancien méditerranéen Abri d'AraguinaSennola (Bonifacio, Corse), Bull. Soc. Préhist. Fr. 78, p. 222-224.

WATTS I. 2010 - The Pigments from Pinnacle Point Cave 13B, Western Cape, South Africa. Journal of Human Evolution, 59, 3-4, p. 392-411.

WYE KR. 1990 - Coquillages. Paris : Arthaud

ZILHAO J. 1997 - O Paleolitico Superior da Estremadura portuguesa, vol. 1, Ed. Colibri.

\section{NOTES}

1. Apart from several non-retouched pieces in Bajocian flint and some of the spear heads, which were excluded due to time restrictions, all the elements kept in individual bags from the excavation or sieving, were analysed. In this way, 716 pieces (665 non-retouched blanks and 51 retouched elements) were studied, including 16 armature elements.

\section{ABSTRACTS}

Discovered in 1990, Peyrazet cave-rock shelter (Creysse, Lot) lies in the Haut-Quercy region at the limits of the Martel limestone plateau, several hundred meters from the current Dordogne River valley. Excavations begun in 2008 produced a Late Glacial archaeo-sequence that sheds new light on several still poorly understood aspects of the archeological record in both the Haut-Quercy region and southwestern France in general. The level overlying the Late Magdalenian occupation produced limited evidence for the Azilian and is stratigraphically separated from the Laborian. This latter techno-complex, dated to the end of the Pleistocene and early Holocene, remains poorly documented in the region, having only been previously identified from two sites in the Quercy. The discovery of a recent Laborian (Epilaborian) occupation at Peyrazet presented the ideal occasion for a collaborative study of the diverse archaeological material recovered from this well-understood archaeo-stratigraphic context. A geoarchaeological analysis produced evidence for both surface runoff and the accumulation of coarse deposits (éboulis) as the principal site formation processes. In the southwest area of the site, a reworked lithofacies demonstrates substantial bioturbation in connection with animal burrowing. Although the presence of rodent, bird, fish, and medium-sized mammals (except hare) cannot be definitively connected to human activity, they nevertheless provide important information concerning the environments exploited by hunter-gatherer groups. Larger species are dominated by red deer whose carcasses were partially processed before being introduced to the site, where meat was subsequently removed and marrow consumed. A functional analysis combined with a typotechnological study of the primarily locally- and regionally-procured lithic material revealed evidence for diverse activities having taken place on-site. An ochre fragment, several bone tools and ornaments equally indicate a large variety of tasks to have been carried out during a single, long occupation or several successive visits. A typo-technological comparison of hunting weaponry (microliths) from sites across a substantial area suggests the assemblage to represent either a Laborian/Epilaborian mix or a unique Epilaborian occupation. This latter case would 
indicate the persistence of older morphotypes alongside the development of new tools forms, a situation already identified at Borie del Rey in the Haut-Agenais but which requires more detailed study supported by new discoveries.

Découverte en 1990, la grotte-abri de Peyrazet (Creysse, Lot, France) se situe dans le Haut-Quercy en bordure du causse de Martel, à quelques centaines de mètres du cours actuel de la Dordogne. Les fouilles menées depuis 2008 livrent une archéoséquence du Tardiglaciaire qui permet de combler certaines lacunes documentaires régionales et plus largement du Sud-Ouest de la France. $\mathrm{Au}$ Magdalénien supérieur succède un niveau ayant donné des indices d'un Azilien sensu lato stratigraphiquement séparé du Laborien, ensemble supérieur qui fait l'objet de cet article. Jusqu'alors ce technocomplexe de la fin du Pléistocène et des débuts de l'Holocène demeurait mal connu dans la région. En effet, seuls des travaux anciens menés dans deux gisements permettaient de noter sa présence en Quercy. La découverte d'un ensemble laborien récent (ou Épilaborien) à Peyrazet est l'occasion de conduire une étude collective des divers vestiges dans un cadre archéostratigraphique mieux maîtrisé. L'analyse géoarchéologique met en évidence l'action conjointe du ruissellement et de l'éboulisation comme principaux responsables de la mise en place des dépôts. Dans la partie S-O du site, un lithofaciès de remaniement indique une bioturbation importante en lien avec le creusement de terriers. Bien que leur origine ne soit pas liée aux activités humaines, les rongeurs, les oiseaux, les poissons et les mésomammifères (excepté le lièvre) apportent des données concernant l'environnement des chasseurs-cueilleurs. La grande faune est dominée par le cerf dont les carcasses pourraient avoir été introduites incomplètes sur le site puis traitées pour en extraire la viande et la moelle. Nous avons bénéficié d'une analyse fonctionnelle croisée à l'étude typo-technologique des vestiges lithiques composés pour l'essentiel de silex locaux et régionaux. Ce double regard a permis de mettre en évidence une diversité d'activités mise en œuvre dans la cavité. Une pièce d'ocre rouge, quelques vestiges d'industrie osseuse et des éléments de parure participent également à la description d'une large gamme de tâches effectuées lors d'un séjour prolongé ou de plusieurs occupations successives. La comparaison des pointes de chasse microlithiques avec d'autres gisements sur une vaste échelle géographique conduit à discuter l'attribution de cet ensemble supérieur à différentes phases du Laborien. L'hypothèse d'un Laborien récent (ou Épilaborien) conduit à réfléchir à une perduration de morphotypes ancestraux parallèlement à de nouveaux types d'armatures, observation déjà réalisée notamment à La Borie del Rey dans le Haut-Agenais mais qui demande encore des précisions et de nouvelles découvertes.

\section{INDEX}

Mots-clés: Quercy, Préboréal, Laborien, Épilaborien, typotechnologie, analyse fonctionnelle, gibier, armement de chasse

Keywords: Quercy, Preboreal, Laborian, Epilaborian, Technotypology, Functional analysis, Game, Hunting weaponry

\section{AUTHORS}

\section{VÉRONIQUE LAROULANDIE}

Laboratoire PACEA (UMR 5199), CNRS, MCC, univ. Bordeaux, Université de Bordeaux, Allée Geoffroy Saint-Hilaire, CS 50023

33615 PESSAC cedex - véronique.laroulandie@u-bordeaux.fr 


\section{JÉRÉMIE JACQUIER}

CReAAH (UMR 6566), université de Rennes I - jacquier.jeremie@gmail.com

\section{SANDRINE COSTAMAGNO}

Laboratoire TRACES (UMR 5608), CNRS, MCC, univ. de Toulouse Jean Jaurès - costamag@univtlse2.fr

\section{PIERRE CHALARD}

Laboratoire TRACES (UMR 5608), CNRS, MCC, univ. de Toulouse Jean Jaurès - costamag@univtlse2.fr

\section{JEAN-BAPTISTE MALLYE}

Laboratoire PACEA (UMR 5199), CNRS, MCC, univ. Bordeaux, Université de Bordeaux, Allée Geoffroy Saint-Hilaire, CS 50023

33615 PESSAC cedex - jb.mallye@u-bordeaux.frs

\section{JEAN-MARC PÉTILLON}

Laboratoire TRACES (UMR 5608), CNRS, MCC, univ. de Toulouse Jean Jaurès - costamag@univtlse2.fr

\section{SOLANGE RIGAUD}

Laboratoire CIRHUS - UMI 3199, CNRS, New York University - srigaud17@gmail.com

\section{AURÉLIEN ROYER}

Laboratoire PACEA (UMR 5199), CNRS, MCC, univ. Bordeaux, Université de Bordeaux, Allée Geoffroy Saint-Hilaire, CS 50023

33615 PESSAC cedex - aurelien_royer@hotmail.com

\section{LUCA SITZIA}

Laboratoire PACEA (UMR 5199), CNRS, MCC, univ. Bordeaux, Université de Bordeaux, Allée Geoffroy Saint-Hilaire, CS 50023

33615 PESSAC cedex - ca3bigio@gmail.com

\section{DAVID COCHARD}

Laboratoire PACEA (UMR 5199), CNRS, MCC, univ. Bordeaux, Université de Bordeaux, Allée Geoffroy Saint-Hilaire, CS 50023

33615 PESSAC cedex - david.cochard@u-bordeaux.fr

\section{LAURE DAYET}

Laboratoire PACEA (UMR 5199), CNRS, MCC, univ. Bordeaux, Université de Bordeaux, Allée Geoffroy Saint-Hilaire, CS 50023

33615 PESSAC cedex - laure.dayet@gmail.com

\section{CÉLIA FAT CHEUNG}

Laboratoire TRACES (UMR 5608), CNRS, MCC, univ. de Toulouse Jean Jaurès - costamag@univtlse2.fr ; 


\section{ALAIN QUEFFELEC}

Laboratoire PACEA (UMR 5199), CNRS, MCC, univ. Bordeaux, Université de Bordeaux, Allée Geoffroy Saint-Hilaire, CS 50023

33615 PESSAC cedex - alain.queffelec@u-bordeaux.fr

FRANÇOIS LACRAMPE-CUYAUBÈRE

Société Archéosphère - f.lacrampe@archeosphere.com 